\title{
ON SOME APPROACHES TO INCREASING PERFORMANCE AND COST-EFFICIENCY OF RUSSIAN REGIONAL AIDS CENTERS
}

\author{
A. E. IVANOV, E. V. GILENKO, E. M. BATUEVA \\ Graduate School of Management, St. Petersburg State University, Russia
}

The paper discusses the problem of counteracting the spread of HIV/AIDS in Russia. This disease is the main cause of death for the Russian working-age population, which annually takes tens of thousands of lives and hinders the achievement of such goals of the Russian state policy as preserving the health and well-being of Russian people. The principal elements of the system of HIV/AIDS counteraction are regional AIDS prevention and control centers (AIDS centers), whose improvement of performance is required by the "State Strategy for Counteracting the Spread of the HIV Infection in the Russian Federation for the period up to 2020 and beyond". In this paper, based on the proposed modification of M. Porter's care delivery value chain model, we demonstrate the ways of enhancing the performance of a regional AIDS center by increasing the value of its services and reducing the costs of their provision due to strengthening the channels of transferring information about HIV/AIDS to the population, improving the accuracy of predicting new registered cases of HIV/AIDS, as well as perfecting public procurement of the necessary medicines and consumables. Our calculations are based on real data of the Perm AIDS center. As a result, relevant recommendations are formulated for the leadership of the Perm AIDS center on the ways of interaction with the population, prediction of new HIV/AIDS cases, and conducting public procurement of drugs and consumables for the needs of the center.

Keywords: regional AIDS centers, care delivery value chain, public procurement, channels of communication with population, prediction of new HIV cases.

JEL: C22; I18; H57

The research was conducted with financial support from St. Petersburg State University (project No. 77100624) Postal address: 3, Volkhovskiy per., Graduate School of Management, St. Petersburg State University, St. Petersburg, 199004, Russia.

(C) A. E. Ivanov, E. V. Gilenko, E. M. Batueva, 2021

https://doi.org/10.21638/spbu18.2021.102 


\section{INTRODUCTION}

The human immunodeficiency virus (HIV), which weakens the human immune system and reduces the body's resistance to infections, at the last stage of its development transforms into the acquired immunodeficiency syndrome (AIDS). At this stage, the weakened human body is unable to resist different infectious diseases, which leads to a substantial decrease in the quality of life, premature disability, and, ultimately, death.

Active counteraction to the disease is carried out both by the humanity at large within the Joint United Nations Program on HIV/ AIDS (hereinafter - the UNAIDS Program) [UNAIDS, 2014], and by national healthcare systems within the corresponding national strategies.

The "State strategy for counteracting the spread of the HIV infection in the Russian Federation for the period up to 2020 and beyond", approved on 20.10.2016 by Order No. 2203-r of the Government of the Russian Federation, considers improvement of activities organization, and of material, technical, and personnel support for specialized medical organizations that provide medical assistance to HIV/AIDS-positive citizens as one of its main goals [State HIV Strategy, 2016, p. 4].

In Russia, the principal elements of the system of HIV/AIDS counteraction are regional AIDS prevention and control centers (hereinafter - AIDS centers), whose improvement of performance is required by the State Strategy for Counteracting the Spread of HIV Infection in the Russian Federation [State HIV Strategy, 2016]. The focus of this study is specifically on the Perm AIDS center, with the main aim being development and justification of recommendations for improving its performance.

To achieve this aim, we apply a number of well-known business-tools for company's performance improvement, such as:

- M. Porter's value chain [Porter, 1985, p. 36], which is used to model the Perm AIDS center's activities;
- care delivery value chain (CDVC) [Porter, Teisberg, 2006, p. 203], which reflects the adaptation of the value chain logic specifically to delivery of health care this tool is used to identify and improve the center's contribution to creating value for its patients;

- the Ansoff model [Ansoff, 1957, p. 114] to support development of the growth strategy for the center.

Thus, with certain limitations ${ }^{1}$, the paper aims to help in developing the Perm AIDS center's growth strategy. Here, by the center's growth strategy we understand a specified set of actions aimed at achieving its goals. These goals include the center's cost reduction, while, at the same time, meeting the indicators of the UNAIDS Program.

To this end, in this paper we:

- propose a modification to the well-known CDVC model for HIV/AIDS care [Rhatigan et al., 2009; Osunyomi, Grobbelaar, 2015, p. 2] by: (1) adding the "outbound logistics" element to the chain of primary activities; and (2) adding the "quality of patient's life" element to the list of patient value components;

- revise the activities within certain elements of the Perm AIDS center's CDVC (such as "prevention" and "outbound logistics") to identify and implement the measures for the center's cost reduction and meeting the criteria of the "90-9090" Program.

Thus, from the theoretical perspective, the paper contributes to the literature, on the one hand, by integrating both medical and nonmedical activities into CDVC, and, on the other hand, by considering the contribution of various activities implemented in the process of medical care provision to:

${ }^{1}$ Due to the paper size limitations, we do not provide a full-fledged strategy development process to be based on identification of the Center's strengths (S), weaknesses (W), opportunities (O), and threats (T), followed by the relevant proposal of a set of measures that would use the Os and strengthen the $\mathrm{Ss}$, as well as neutralize the Ts and the Ws. 
- creation of value for patients (better informing of the patients; optimizing the set of measurements of health parameters, facilitating access to health care and directly improving their health status);

- reduction of organizational costs.

To the best of our knowledge, there are no academic studies on the application of CDVC to modeling of health care delivering in Russia, despite the fact that the value chain model is among the most important strategic tools taught in Russian business schools [Array, Verkhovskaya, Klemina, 2017, p. 302].

The practical (managerial) contributions of the paper are as follows.

1. Based on conducted own survey of people in Perm, we provide recommendations aimed at improving the center's marketing effectiveness ${ }^{2}$ related to informing the people of Perm about the HIV/AIDS disease.

2. Using the information on new registered HIV/AIDS cases, available from the center for the period from 2005 to 2020 , we propose an improvement to the methodology for new HIV/AIDS cases forecasting and demonstrate its better performance as compared to the one currently used by the center.

3. After thoroughly analyzing the efficiency of the center's procurement process in 2019, we propose specific steps for improving the public procurement regulation and the purchasing procedure of medicines and consumables for diagnostic activities in the Russian Federation, at large, and for the Perm AIDS center, in particular.

Thus, it is expected that the obtained results will contribute to:

- achievement of the national goal of saving the Russian population, improving health and well-being of people, and in-

\footnotetext{
${ }^{2}$ In this paper, "effectiveness" reflects assessment of the degree of achievement of the set goals, while "efficiency" implies comparison of the outcomes and the resources spent for obtaining these outcomes.
}

creasing their life expectancy [Presidential Order, 2020];

- wider application of CDVC to modeling of the service delivery process and developing of growth strategies for medical organizations;

- improving effectiveness and efficiency of procurement of medicines and consumables for diagnostic activities of AIDS centers and other healthcare organizations;

- improving the Perm AIDS center's performance.

The rest of the paper is organized as follows. Section 1 gives details on the modern system of counteraction to HIV/AIDS spread in the Russian Federation, discusses the role of Russian regional AIDS centers in this process, and formally shows an application of the CDVC model to description of an AIDS center's activities. In Section 2 we focus specifically on the Perm AIDS center and provide relevant recommendations on improving its performance.

\section{THE SYSTEM OF COUNTERACTION TO HIV/AIDS SPREAD IN THE RUSSIAN FEDERATION}

In this section, to provide further motivation for the current study, we discuss the principal elements of the modern system of counteraction to HIV/AIDS spread in the Russian Federation, the role of Russian regional AIDS centers in this process, and show an application of the CDVC model to description of an AIDS center's activities.

\subsection{Spread of HIV/AIDS as a threat to the national interests of Russia}

Since 2012, the principal directions of development and speed of growth of the Russian economy and society have been determined to a great extent by the inaugural decrees of the 
Life expectancy in the Russian Federation, years, 2003-2018

\begin{tabular}{l|c|c|c}
\hline \multicolumn{1}{c|}{ Year } & All population & Male & Female \\
\hline 2003 & 64.84 & 58.53 & 71.85 \\
\hline 2004 & 65.31 & 58.91 & 72.36 \\
\hline 2005 & 65.37 & 58.92 & 72.47 \\
\hline 2006 & 66.69 & 60.43 & 73.34 \\
\hline 2007 & 67.61 & 61.46 & 74.02 \\
\hline 2008 & 67.99 & 61.92 & 74.28 \\
\hline 2009 & 68.78 & 62.87 & 74.79 \\
\hline 2010 & 68.94 & 63.09 & 74.88 \\
\hline 2011 & 69.83 & 64.04 & 75.61 \\
\hline 2012 & 70.24 & 64.56 & 75.86 \\
\hline 2013 & 70.76 & 65.13 & 76.30 \\
\hline 2014 & 70.93 & 65.29 & 76.47 \\
\hline 2015 & 71.39 & 65.92 & 76.71 \\
\hline 2016 & 71.87 & 66.50 & 77.06 \\
\hline 2017 & 72.70 & 67.51 & 77.64 \\
\hline
\end{tabular}

S o u r c e: [Rosstat, 2019].

President. In his eleven decrees dated 07.05.2012 (No. 596-606), the President of the Russian Federation set 218 different goals, the achievement of which was to be provided by the Russian Government over the period 2012-2020.

As compared to previous inaugural decrees of the President, the decree of 07.05.2018, No. 204 "On national goals and strategic objectives for the development of the Russian Federation for the period up to 2024" nine goals were identified, including increasing of life expectancy in Russia up to 78 years by 2024 (and up to 80 years by 2030).

Table 1 gives information on life expectancy in the Russian Federation. The table demonstrates that, to achieve the above-mentioned goal, over the period 2019-2024 the life expectancy is to be increased by 5 years (from 72.91 in 2018 up to 78 years in 2024). It also shows that despite a long-term upcoming trend in this indicator, a 5-year growth by 2018 took as many as eleven years (started in 2008). To be completely fair, it should be noted that the current COVID-19 situation called for certain corrections - the decree of the President No. 474 of 21.07.2020, "On the national development goals of the Russian Federation for the period up to 2030", now sets the goal of achieving the specified value of 78 years over the forthcoming 10 years.

To achieve this goal, the Ministry of Health of the Russian Federation (MHRF) developed a national project "Healthcare" [MHRF, 2019] which, in particular, comprises two directions of realization ("Cancer control" and "Cardiovascular disease control") with one of the principal objectives being reduction in 
Table 2

Number of deaths of the Russian population due to different causes, 2019

\begin{tabular}{l|c|c}
\hline \multirow{2}{*}{ Cause of death } & \multicolumn{2}{c}{ Died in 2019 } \\
\cline { 2 - 3 } & Total, people & $\%$ \\
\hline Died (total) & 1800677 & 100.00 \\
\hline Infectious and parasitic diseases, including: & 31159 & 1.73 \\
HIV/AIDS & 18928 & 1.05 \\
Neoplasms & 295456 & 16.41 \\
Diseases of the circulatory system & 841176 & 46.71 \\
Diseases of the respiratory organs & 57957 & 3.22 \\
Diseases of the digestive organs & 97323 & 5.40 \\
Diseases of the nervous system & 100285 & 5.57 \\
Endocrine system diseases, eating and metabolic disorders & 42762 & 2.37 \\
\hline Other causes & 206417 & 11.46 \\
\hline External causes & 128142 & 7.12 \\
\hline
\end{tabular}

S o u r c e: [Rosstat, 2019].

mortality of the working-age population by $26 \%$ - from 473.4 (in 2017) to 350.0 (in 2024) cases per 100 thousand people.

The modern medical statistics distinguishes several main classes of causes of death, such as infectious and parasitic diseases, neoplasms, diseases of the circulatory system, diseases of the respiratory and digestive organs, and some other. Table 2 contains information on the distribution of the number of deaths in 2019 over these classes.

The principal question of this study is increasing the effectiveness of the set of measures to counteract the spread of HIV/AIDS in the Russian Federation. An indirect confirmation of the importance of the problem under consideration is, in particular, the fact that, starting from August 2018, medical statistics distinguishes the cause of death from HIV/ AIDS in the class of "infectious and parasitic diseases".

From this perspective, the importance of counteracting the spread of HIV/AIDS is of highest priority, because, as compared to other causes of death, AIDS-related mortality occurs mainly in the group of working-age people. In 2018, AIDS-related mortality in the age group of $25-54$ years was $82.6 \%$ of the total number of deaths (Figure 1).

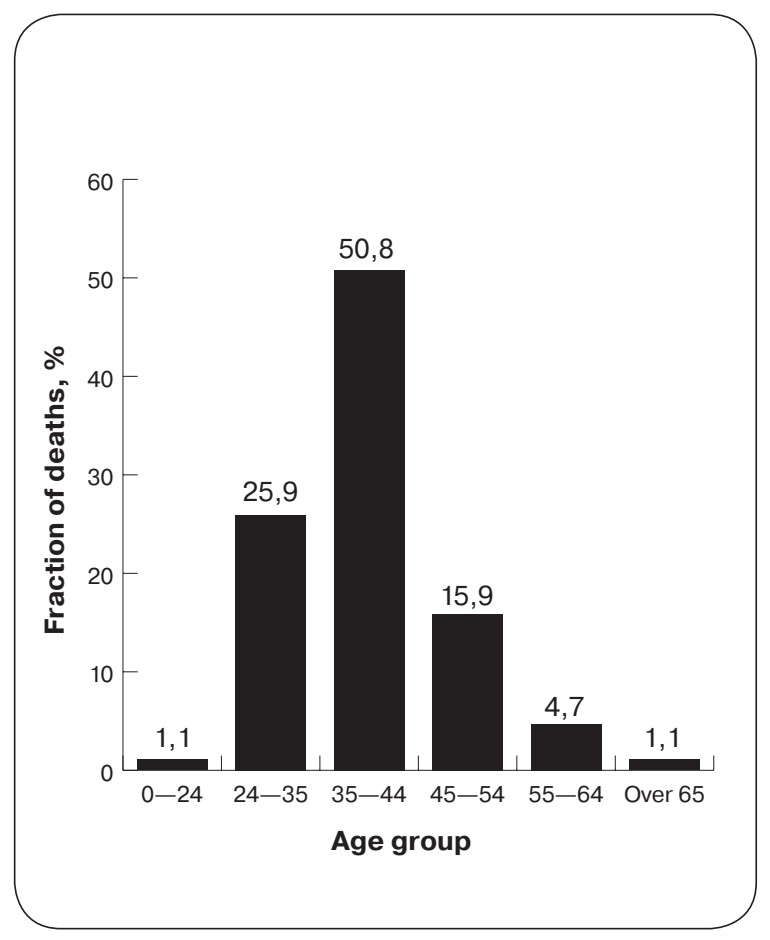

Fig. 1. Age distribution of the number of deaths caused by HIV/AIDS in Russia, 2018 B as ed on: [FRIHOI, 2018, p. 12]. 
Prevalence and effectiveness of counteraction to HIV/AIDS in Russia and in the world, $\mathrm{mln}$ people, 2019

\begin{tabular}{l|c|c}
\hline \multicolumn{1}{c|}{ Indicator } & \multicolumn{2}{c}{ Total } \\
\cline { 2 - 3 } & Russia & World \\
\hline Cumulative total number of people diagnosed with HIV/AIDS & 1.42 & 75.7 \\
(as of 31.12.2019), of which: & 0.36 & 32.7 \\
- died & 1.07 & 38.0 \\
\hline alive & 0.09 & 1.7 \\
\hline New registered HIV/AIDS cases in 2019 & 0.03 & 0.7 \\
\hline Died in 2019 & 0.78 & 30.8 \\
\hline Received therapy & 0.53 & 25.4 \\
\hline Suppressed the viral load & 0.41 & 22.4 \\
\hline
\end{tabular}

B a s ed on: [ITPC, 2019; UNAIDS, 2020].

Moreover, in 2018, the HIV/AIDS cause of death hit the top in the structure of mortality for young population aged 18-44. In this age group, the rate of AIDS mortality was $15.8 \%$, as compared to other death causes such as malignant neoplasms (13.1\%), respiratory diseases (5.4\%), diseases of digestion $(14.9 \%)$ and the nervous system $(3.6 \%)$, ischemic heart disease (8.4\%), cerebrovascular diseases $(5.1 \%)$, tuberculosis $(3.3 \%)$ [FRIHOI, 2018, p. 13].

Let us estimate the scale of prevalence ${ }^{3}$ and the effectiveness of HIV/AIDS counteraction in the Russian Federation in comparison with the global data (Table 3). Comparison of the last two columns of Table 3 allows us to make the following conclusions.

First, the cumulative number of Russian people who died due to HIV/AIDS comprises approximately $1 \%(0.355 / 32.7)$ of the cumulative number of such deaths in the world. But, second, specifically in 2019 , this ratio is already $4.79 \%$ (33 577/700 000), which, combined with $5.57 \%(94668 / 1700000)$ of new registered HIV/AIDS cases, speaks about the

\footnotetext{
${ }^{3}$ Prevalence is the total number of infected people registered within a certain territory by the end of the corresponding year.
}

need to put more effort in HIV/AIDS counteraction in the modern Russia.

This information clearly illustrates the fact that the current spread of HIV/AIDS in the Russian Federation is a direct threat to the long-term Russian national interests, specifically, to increasing life expectancy of the Russian population.

To determine the effectiveness of HIV/AIDS counteraction, we will use the so-called "9090-90" principle - a modern approach which is based on the UNAIDS Program proposed in 2014 (see [UNAIDS, 2014]), which, in particular, set the following goals by the end of 2020 : - $90 \%$ of people (children, adolescents and adults) living with HIV/AIDS know their HIV-status;

- $90 \%$ of people who know their HIVpositive status have access to treatment - antiretroviral therapy (ART);

- $90 \%$ of people on treatment have suppressed viral loads.

Achievement of these goals means that approximately $73 \%$ of the total number of people living with HIV/AIDS are supposed to improve their health status yearly.

Using the information from Table 3, we can determine the rate of achievement of the goals

PЖM 19 (1): 35-66 (2021) 


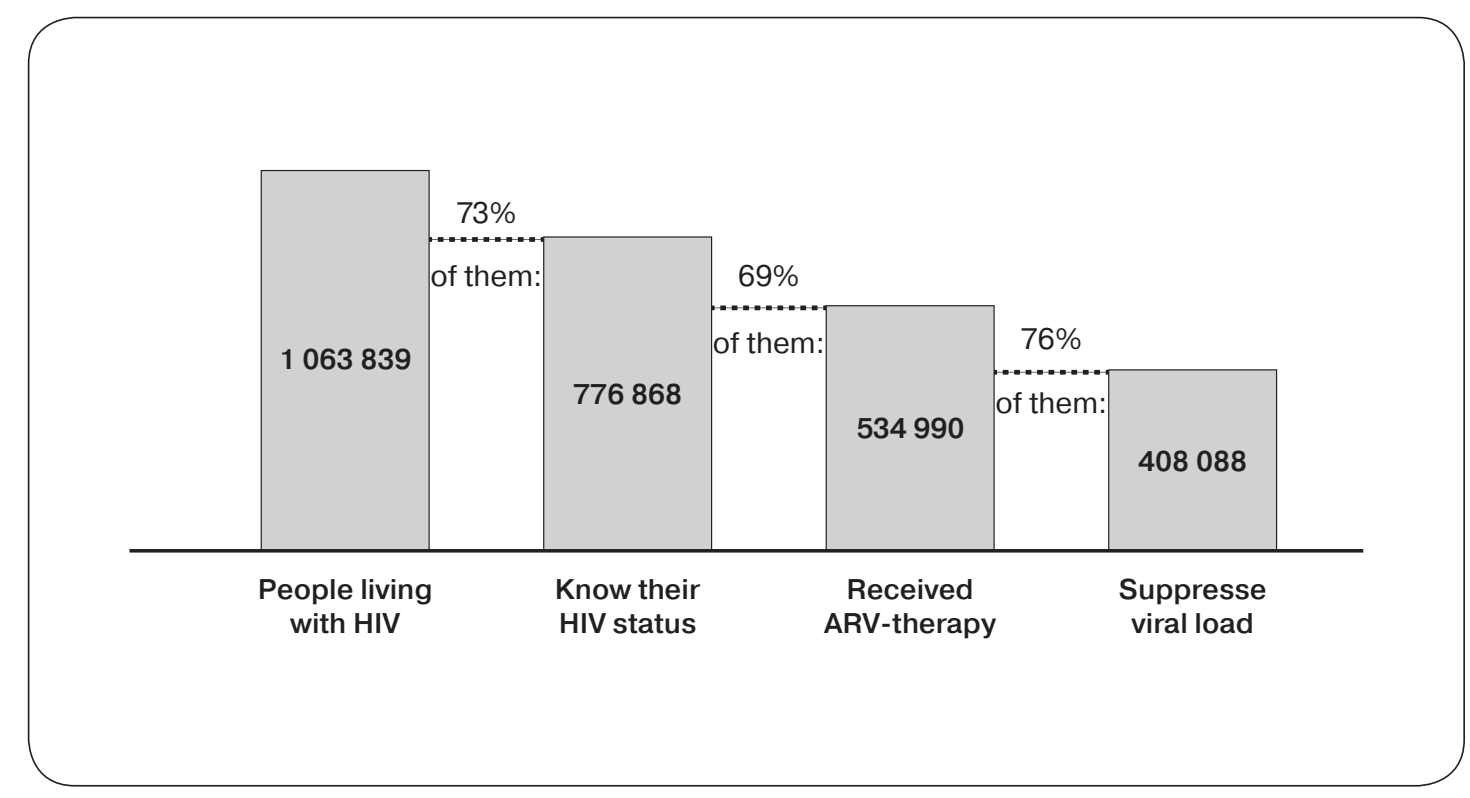

Fig. 2. Meeting the "90-90-90" principle: Russia (people)

B a se d on: [ITPC, 2019].

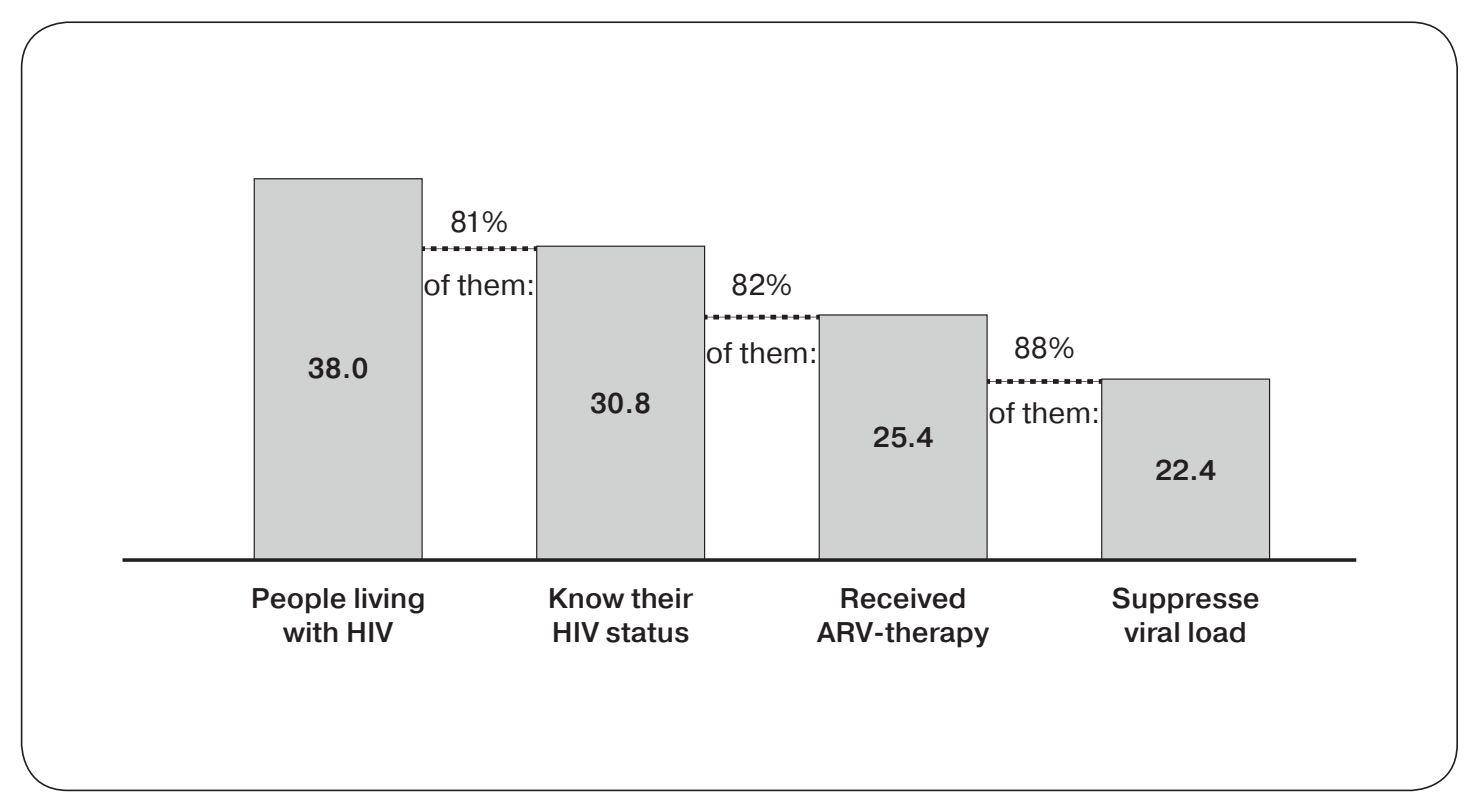

B a sed on: [UNAIDS, 2020].

Fig. 3. Meeting the "90-90-90" principle: world (mln people)

of the "90-90-90" Program in the Russian Federation (Figure 2) and globally (Figure 3).

Analysis of these figures leads to the conclusion that principal efforts of the relevant Russian authorities should be focused on in- creasing the number of HIV-positive people who:

- are aware of their HIV status;

- get antiretroviral therapy (ART);

- improve their health status. 
Modes and ways of HIV/AIDS transmission

\begin{tabular}{c|c}
\hline Mode & \multicolumn{1}{c}{ Way } \\
\hline Natural & $\begin{array}{l}\text { Contact - realized mainly during sexual intercourse (both homosexual and heterosexual) } \\
\text { - Vertical - infection of a child from an HIV-positive mother }\end{array}$ \\
\hline \multirow{2}{*}{ Artificial } & $\begin{array}{l}\text { Via non-medical invasive procedures - intravenous drug administration; cosmetic, mani- } \\
\text { cure, and pedicure procedures with non-sterile instruments, etc. } \\
\text { - Via medical invasive procedures - invasive interventions in medical organizations }\end{array}$ \\
\hline
\end{tabular}

S o u r c e: [SanPin, 2011].

\subsection{The role of regional AIDS centers in identification and treatment of HIV-positive people}

The principal obligations of the Russian government in the area of HIV/AIDS counteracting are regulated by Federal Law of the Russian Federation No. 38-FZ of 30.03.1995 "On prevention of spread of disease caused by the human immunodeficiency virus (HIV) in the Russian Federation". Specifically, the government guarantees the following:

- availability of medical examination for the HIV infection to people;

- provision of medical assistance to HIVpositive citizens of the Russian Federation in accordance with the program of state guarantees of free medical care to the citizens;

- free provision of medicines for the treatment of HIV infection on an outpatient basis in medical organizations subordinate to federal or regional executive authorities.

It should be noted that HIV infection is spread both naturally and artificially (Table 4).

The main population groups vulnerable to the HIV-infection are: injected-drug users, commercial sex workers, prisoners, and some other groups [SanPin, 2011]. It is recommended that they are voluntarily involved in medical examination to detect HIV-infection, e.g., when they seek for medical care. In turn, donors of blood and other biological materials, doctors, middle and junior medical personnel of the Centers for HIV/AIDS Prevention and
Control, medical workers in hospitals (departments) of a surgical profile, etc. are subject to mandatory medical examination for HIVinfection [SanPin, 2011].

The standardized methods of laboratory diagnosis of HIV are enzyme-linked immunosorbent assay (ELISA) and chemiluminescence immunoassay (CLIA), which can be performed by public medical institutions for free or by private clinics on a commercial basis. If the test gives a positive result, then the patient is consecutively re-tested twice. After that, the biological material is sent to a state reference laboratory for further analysis. As a rule, these are the laboratories of regional AIDS centers.

The concept of "value" has long time been key for modern economic and management research [Golubeva, Gilenko, Dzhedzheya, 2019]. From this perspective, the activities of AIDS centers (which are the main elements in the state system of HIV/AIDS control and prevention) is well-captured by the generic value chain (VC) model proposed by M. Porter in the early 1980-s [Porter, 1985]. Within this model, the operation of an organization is represented as a set of: (1) primary activities carried out by its strategic business units (SBUs) that create various products for different groups of consumers or provide them with services; and (2) support activities that the organization conducts for its SBUs (Figure 4).

As the product/service passes through each of the steps in this chain (Inbound logistics, Operations, Outbound logistics, Marketing \& sales, Service), on the one hand,

PЖM 19 (1): 35-66 (2021) 


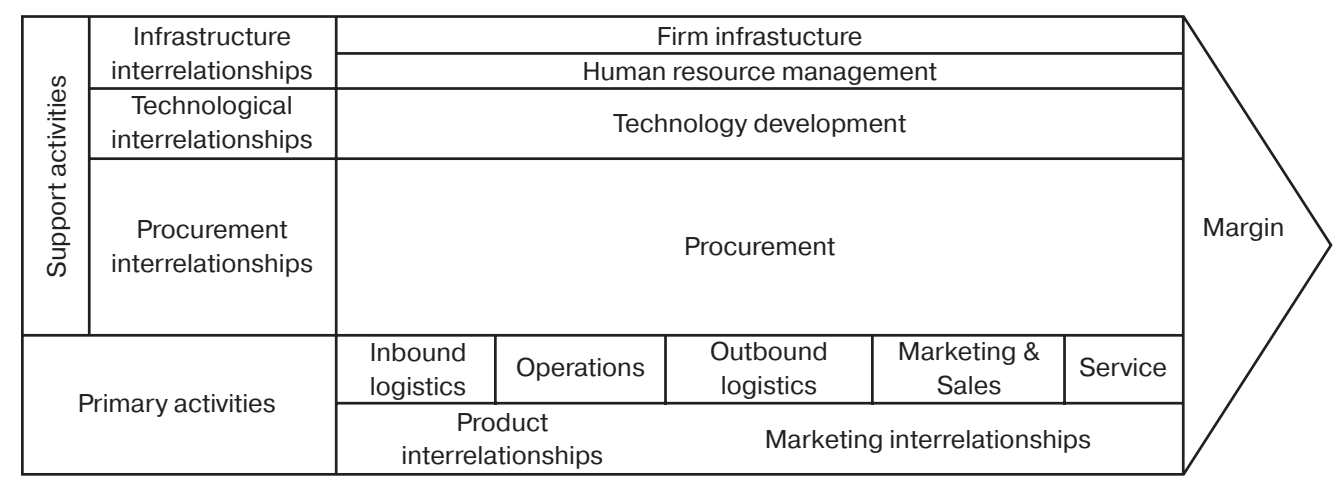

Based on: [Porter, 1985, p. 37].

Fig. 4. Generic value chain model

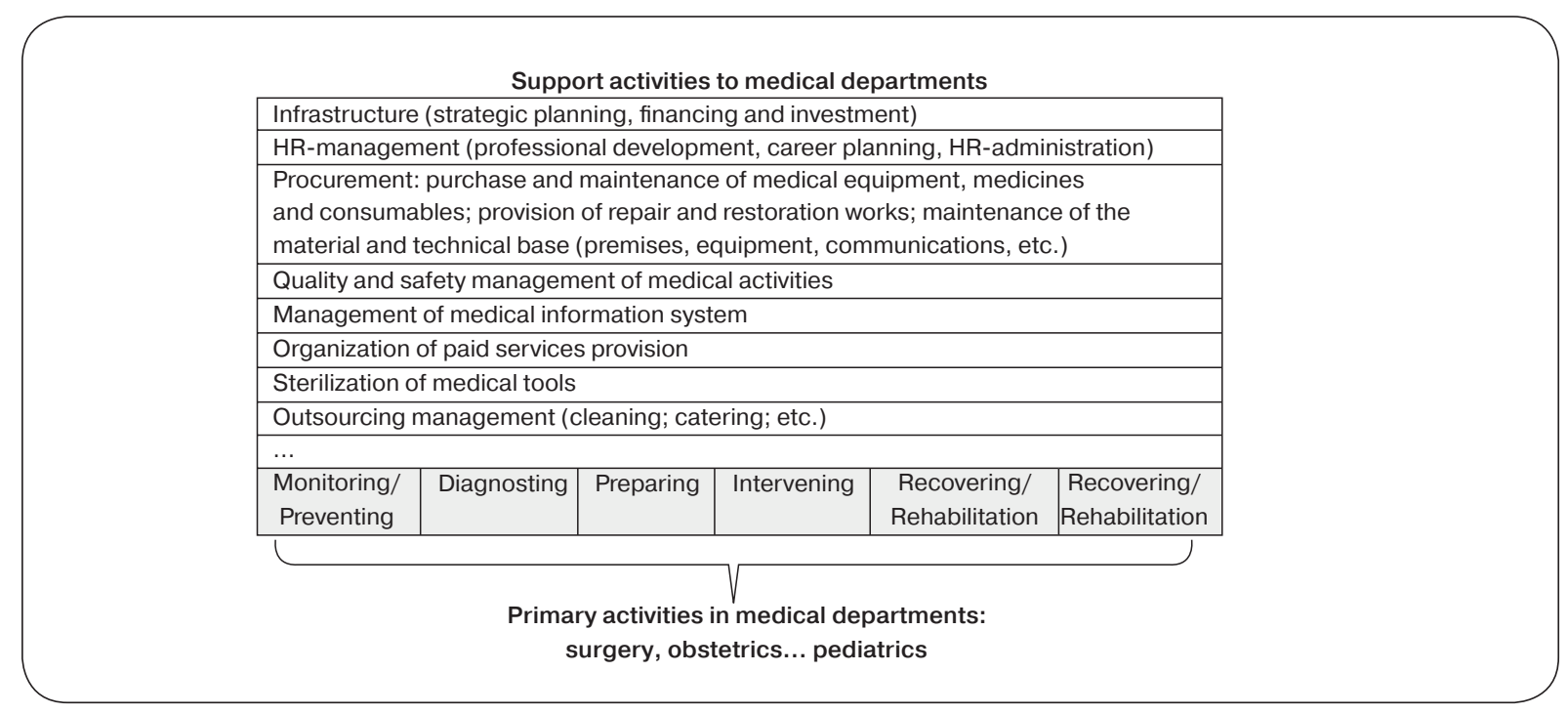

Fig. 5. Typical value chain of an in-patient hospital

B as ed on: [Porter, Teisberg, 2006].

certain value is created for the consumer, and, on the other hand, costs are accumulated. Correspondingly, the success of an SBU functioning is determined by whether consumers are willing to pay for the created value more than the amount of accumulated costs.

Application of the VC model in healthcare requires identification of primary and sup- portive activities of a medical organization. That was done for a typical in-patient hospital in Figure 5. On the one hand, the table contains Porter's disaggregation of the element "Operations" into several sub-elements of care delivering [Porter, Teisberg, 2006, p. 204], leaving aside, for now, other primary activities of a hospital (Figure 5). 
On the other hand, it reflects the experience of development of strategies for different healthcare organizations by the students of retraining program "Healthcare Management" (owners and top-managers of hospitals), delivered at GSOM SPbU since 2009, which gave a lot of examples of hospital's supporting activities and demonstrated that the VC model can be fruitfully extended by a list of hospital's SBUs.
About two decades after its creation, the VC model was amended by M. Porter himself to reflect value creation in the process of care delivery. The modified model (Table 5), named CDVC, “... first describes the current activities in each medical condition and then, more important, analyzes ways to increase the value of services to patients" [Porter, Teisberg, 2006, p. 203]. In the top part of CDVC, the value created at each of the steps

The CDVC model: the case of HIV/AIDS control

\begin{tabular}{|c|c|c|c|c|c|c|}
\hline $\begin{array}{l}\text { Patient's value } \\
\text { compounds }\end{array}$ & \multicolumn{6}{|c|}{ Element of value chain } \\
\hline $\begin{array}{l}\text { Informing } \\
\text { What do } \\
\text { patients need } \\
\text { to be educated } \\
\text { about? }\end{array}$ & $\begin{array}{l}\text { - Lifestyle } \\
\text { counseling } \\
\text { - Self- } \\
\text { management }\end{array}$ & $\begin{array}{l}\text { - Lifestyle } \\
\text { counseling } \\
\text { - Explanation } \\
\text { of the diag- } \\
\text { nosis and the } \\
\text { implications } \\
\text { - Explaining } \\
\text { the course of } \\
\text { HIV and } \\
\text { prognosis }\end{array}$ & $\begin{array}{l}\text { - Lifestyle } \\
\text { counseling } \\
\text { - Explanation } \\
\text { of the diag- } \\
\text { nosis and the } \\
\text { implications }\end{array}$ & $\begin{array}{l}\text { Explanation } \\
\text { of medica- } \\
\text { tion instruc- } \\
\text { tions and } \\
\text { side-effects }\end{array}$ & $\begin{array}{l}\text { - Medication } \\
\text { compliance }\end{array}$ & $\begin{array}{l}\text { - Managing } \\
\text { complications } \\
\text { - Explanation } \\
\text { of the co- } \\
\text { morbid diag- } \\
\text { noses and the } \\
\text { implications } \\
\text { - End-of-life } \\
\text { counseling }\end{array}$ \\
\hline $\begin{array}{l}\text { Measuring } \\
\text { What measures } \\
\text { need to be } \\
\text { collected? }\end{array}$ & $\begin{array}{l}\text { - HIV testing } \\
\text { Tcreen for } \\
\text { TB and, if } \\
\text { indicated, si- } \\
\text { multaneously } \\
\text { screen for } \\
\text { sexually } \\
\text { transmitted } \\
\text { infections } \\
\text { (chlamydia, } \\
\text { gonorrhea) } \\
\text { Collect base- } \\
\text { line demo- } \\
\text { graphics }\end{array}$ & $\begin{array}{l}\text { - HIV testing } \\
\text { for others at } \\
\text { risk } \\
\text { - HIV staging } \\
\text { - Clinical ex- } \\
\text { amination, } \\
\text { CD4+ count, } \\
\text { and other } \\
\text { labs } \\
\text { - Testing for } \\
\text { common co- } \\
\text { morbidities }\end{array}$ & $\begin{array}{l}\text { - CD4+ count } \\
\text { monitoring } \\
\text { (continuous } \\
\text { staging) } \\
\text { - Continuous } \\
\text { assessment } \\
\text { of co-morbid- } \\
\text { ities } \\
\text { - Regular clin- } \\
\text { ical examina- } \\
\text { tions to as- } \\
\text { sess for dis- } \\
\text { ease } \\
\text { progression } \\
\text { - Socio- } \\
\text { economic and } \\
\text { nutrition as- } \\
\text { sessment }\end{array}$ & $\begin{array}{l}\text { - CD4+ count } \\
\text { monitoring } \\
\text { (continuous } \\
\text { staging) } \\
\text { - Monthly pri- } \\
\text { mary care } \\
\text { assessment } \\
\text { - HIV testing } \\
\text { for others at } \\
\text { risk } \\
\text { - Laboratory } \\
\text { evaluation } \\
\text { for medica- } \\
\text { tion initia- } \\
\text { tion }\end{array}$ & $\begin{array}{l}\text { - HIV staging } \\
\text { and medica- } \\
\text { tion re- } \\
\text { sponse } \\
\text { - High fre- } \\
\text { quency pri- } \\
\text { mary care } \\
\text { assessment } \\
\text { - Assessing/ } \\
\text { managing } \\
\text { complica- } \\
\text { tions of } \\
\text { therapy } \\
\text { HIV testing } \\
\text { for others } \\
\text { at risk (bi- } \\
\text { annually) } \\
\text { Laboratory } \\
\text { evaluation }\end{array}$ & $\begin{array}{l}\text { - HIV staging } \\
\text { and medica- } \\
\text { tion response } \\
\text { - Monthly pri- } \\
\text { mary care as- } \\
\text { sessment } \\
\text { - Laboratory } \\
\text { evaluation }\end{array}$ \\
\hline
\end{tabular}


Table 5 (end)

\begin{tabular}{|c|c|c|c|c|c|c|}
\hline $\begin{array}{l}\text { Patient's value } \\
\text { compounds }\end{array}$ & \multicolumn{6}{|c|}{ Element of value chain } \\
\hline $\begin{array}{l}\text { Accessing } \\
\text { Where do } \\
\text { patient care } \\
\text { activities take } \\
\text { place? }\end{array}$ & $\begin{array}{l}\text { - Meeting pa- } \\
\text { tients in } \\
\text { high risk set- } \\
\text { tings } \\
\text { - Primary care } \\
\text { clinics } \\
\text { - Testing cent- } \\
\text { ers }\end{array}$ & $\begin{array}{l}\text { - Primary } \\
\text { care clinics } \\
\text { - Laboratories } \\
\text { (on-site at } \\
\text { primary clin- } \\
\text { ic) } \\
\text { - Testing } \\
\text { Centers }\end{array}$ & $\begin{array}{l}\text { - Primary } \\
\text { care clinics } \\
\text { - Support } \\
\text { groups } \\
\text { - Laboratories } \\
\text { (on-site at } \\
\text { primary clin- } \\
\text { ic) } \\
\text { - Pharmacy } \\
\text { - Food centers } \\
\text { - Home visits }\end{array}$ & $\begin{array}{l}\text { - Primary } \\
\text { care clinics } \\
\text { - Support } \\
\text { groups } \\
\text { - Laboratories } \\
\text { (on-site at } \\
\text { primary clin- } \\
\text { ic) } \\
\text { - Pharmacy } \\
\text { - Community } \\
\text { health work- } \\
\text { ers/home } \\
\text { visits }\end{array}$ & $\begin{array}{l}\text { - Primary } \\
\text { care clinics } \\
\text { - Support } \\
\text { groups } \\
\text { - Laboratories } \\
\text { (on-site at } \\
\text { primary } \\
\text { clinic) } \\
\text { - Pharmacy } \\
\text { - Community } \\
\text { health work- } \\
\text { ers/home } \\
\text { visits }\end{array}$ & 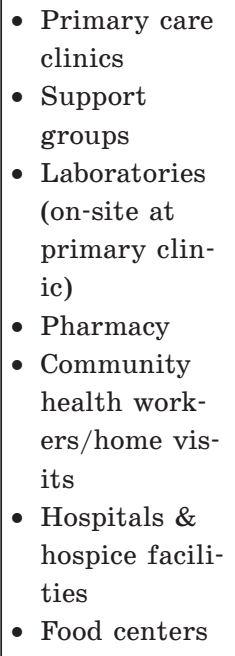 \\
\hline & $\begin{array}{c}\text { Prevention } \\
\text { and Screening }\end{array}$ & $\begin{array}{c}\text { Diagnosing } \\
\text { and Staging } \\
\text { (if }+ \text { in screen- } \\
\text { ing stage) }\end{array}$ & $\begin{array}{l}\text { Pre Anti- } \\
\text { Retroviral } \\
\text { Medical and } \\
\text { Psychosocial } \\
\text { Management }\end{array}$ & $\begin{array}{c}\text { Intervening / } \\
\text { ARV-Initiation }\end{array}$ & $\begin{array}{l}\text { Continuous } \\
\text { Disease } \\
\text { Management }\end{array}$ & $\begin{array}{l}\text { Management of } \\
\text { Complications } \\
\text { and } \\
\text { Clinical } \\
\text { Deterioration }\end{array}$ \\
\hline $\begin{array}{l}\text { Care delivery } \\
\text { What activities } \\
\text { are performed } \\
\text { at each stage? }\end{array}$ & $\begin{array}{l}\text { - Identifying } \\
\text { high risk in- } \\
\text { dividuals } \\
\text { - Testing at- } \\
\text { risk individ- } \\
\text { uals } \\
\text { - Promoting } \\
\text { appropriate } \\
\text { risk reduc- } \\
\text { tion strate- } \\
\text { gies } \\
\text { - Modifying } \\
\text { behavioral } \\
\text { risk factors } \\
\text { - Connecting } \\
\text { patients with } \\
\text { primary care } \\
\text { system } \\
\text { - Creating a } \\
\text { medical re- } \\
\text { cord }\end{array}$ & $\begin{array}{l}\text { - Formal diag- } \\
\text { nosis and } \\
\text { staging } \\
\text { - Determine } \\
\text { method of } \\
\text { transmission } \\
\text { and others at } \\
\text { potential } \\
\text { risk } \\
\text { - Identify oth- } \\
\text { ers at risk } \\
\text { - Determine } \\
\text { TB, syphilis, } \\
\text { and status of } \\
\text { other sexual- } \\
\text { ly transmit- } \\
\text { ted diseases } \\
\text { - Create man- } \\
\text { agement } \\
\text { plan, includ- } \\
\text { ing schedul- } \\
\text { ing of fol- } \\
\text { low-up visits }\end{array}$ & $\begin{array}{l}\text { - Formulate a } \\
\text { treatment } \\
\text { plan } \\
\text { - Initiate ther- } \\
\text { apies that } \\
\text { can delay on- } \\
\text { set } \\
\text { - Limit co- } \\
\text { morbidities } \\
\text { that affect } \\
\text { progression } \\
\text { of disease } \\
\text { - Improve pa- } \\
\text { tient aware- } \\
\text { ness of dis- } \\
\text { ease progres- } \\
\text { sion, } \\
\text { prognosis, } \\
\text { and trans- } \\
\text { mission } \\
\text { Connect pa- } \\
\text { tient to care } \\
\text { team, includ- } \\
\text { ing commu- } \\
\text { nity health } \\
\text { work }\end{array}$ & $\begin{array}{l}\text { - Initiate com- } \\
\text { prehensive } \\
\text { antiretrovi- } \\
\text { ral therapy } \\
\text { and assess } \\
\text { medication } \\
\text { readiness } \\
\text { - Prepare pa- } \\
\text { tient for dis- } \\
\text { ease progres- } \\
\text { sion and } \\
\text { side-effects } \\
\text { of associated } \\
\text { treatment } \\
\text { Manage sec- } \\
\text { ondary infec- } \\
\text { tions and as- } \\
\text { sociated ill- } \\
\text { nesses }\end{array}$ & $\begin{array}{l}\text { - Managing } \\
\text { effects of } \\
\text { associated } \\
\text { illnesses } \\
\text { - Determine } \\
\text { supporting } \\
\text { nutritional } \\
\text { modifica- } \\
\text { tions } \\
\text { - Preparing } \\
\text { patient for } \\
\text { end-of-life } \\
\text { management } \\
\text { - Primary } \\
\text { care and } \\
\text { health main- } \\
\text { tenance }\end{array}$ & $\begin{array}{l}\text { - Identifying } \\
\text { clinical and } \\
\text { laboratory de- } \\
\text { terioration } \\
\text { - Initiating sec- } \\
\text { ond-line, } \\
\text { third-line } \\
\text { drug therapies } \\
\text { - Managing } \\
\text { acute illness } \\
\text { and opportun- } \\
\text { istic infection } \\
\text { either through } \\
\text { aggressive } \\
\text { outpatient } \\
\text { management } \\
\text { or hospitaliza- } \\
\text { tion } \\
\text { Managing side } \\
\text { effects of } \\
\text { treatment } \\
\text { Provide addi- } \\
\text { tional commu- } \\
\text { nity/social } \\
\text { support if } \\
\text { needed }\end{array}$ \\
\hline
\end{tabular}

B ased on: [Rhatigan et al., 2009]. 
is structured according to the following positions:

- informing of the patient;

- measuring certain parameters of the patient's health status;

- accessing to the components of medical services.

In contrast to the VC model, the bottompart of CDVC contains activities which are performed in each element of the chain, combining the primary ones and the supporting ones (including outsourcing, if any).

There is a lot of cases of application of CDVC to value creation modeling in treatment of various diseases: chronic kidney disease and breast cancer [Porter, Teisberg, 2006], severe knee osteoarthritis requiring replacement [Kaplan, Porter, 2011], etc. ${ }^{4}$ Also, Table 5 demonstrates the application of CDVC to HIV/AIDS control [Rhatigan et al., 2009; Osunyomi, Grobbelaar, 2015; Porter, 2010].

Still, it seems that the list of the abovementioned patient value components (Informing, Measuring, and Accessing; see also Table 5) is not quite complete, since each of them do not reflect the contribution of medical treatment to improvement of the patient's health status in such cases as, for example, normalizing the patient's blood pressure or relieving their pain. We suggest considering patient's health status improvement as an independent component of value for a patient ${ }^{5}$.

Let us consider the problem of strategy development for a typical AIDS center. Of two main types of strategies for a center growth and competitive - the latter one is irrelevant in this case, since an AIDS center has a monopoly on approving the HIV-positive status, providing patients with medicines, and so on. To help developing the center's growth strategy, we go over the elements of the VC model trying to identify the measures

\footnotetext{
${ }^{4}$ However, the authors are not aware of such publications in the Russian academic literature.

${ }^{5}$ Identification of a complete list of components of value for a patient is out of the scope of this paper.
}

that would cut costs or help creating additional value for patients. Thus, the more comprehensive the list of CDVC elements (links of the chain) is, the better results this approach will provide.

However, the introduced CDVC model is restricted only to primary medical activities (see Table 5) and does not contain other elements of VC (Figure 4).

We propose to modify CDVC in the following ways:

- add patient's health status improvement to the patient's value components;

- add "inbound logistics" to the list of chain elements;

- bind together the elements of patient treatment (delaying progression, initiating ART, ongoing disease management, and management of clinical deterioration) within the "Intervening" element;

- change the outlook of CDVC (see Table 5) the way presented in Table 6 (with columns marked with Latin letters and rows marked with Arabic numbers);

- to give CDVC the outlook of an MS Excel spreadsheet.

Given these suggestions, we construct a simplified CDVC for HIV/AIDS control which reflects the authors' contribution to the growth strategy development of a typical AIDS center (see Table 6, cells A5-A8 and B7).

As mentioned in the introduction, in this paper we focus on the activities of the state healthcare institution "Perm Regional Center for HIV/AIDS and Infectious Diseases Prevention and Control" (the Perm AIDS center). The choice of this specific center is justified, in particular, by the fact that the Perm region is one of the Russian regions most prone to HIV infection (Table 7) in terms of morbidity (new cases of HIV infection per 100000 people) and prevalence (HIV-positive citizens per 100000 people).

The unfavorable (Table 3) HIV/AIDS situation in Russia calls for serious and indepth elaboration of a growth strategy for the Russian AIDS centers. Let us consider three alternative variants of such strategy for the Perm AIDS center - expansion, sta- 
Table 6

Modified value chain model for an AIDS center: selected activities

\begin{tabular}{|c|c|c|c|c|c|c|}
\hline & Column & $\mathbf{A}$ & B & $\mathbf{C}$ & D & Row \\
\hline & Informing & & $\begin{array}{l}\text { Preparation and } \\
\text { distribution of } \\
\text { information } \\
\text { materials }\end{array}$ & $\begin{array}{l}\text { Issuance of an } \\
\text { opinion on the } \\
\text { presence of HIV } \\
\text { infection }\end{array}$ & & 1 \\
\hline 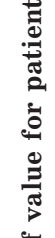 & Measuring & & $\begin{array}{l}\text { Medical examina- } \\
\text { tions as part of } \\
\text { off-clinic events }\end{array}$ & $\begin{array}{l}\text { Determining the } \\
\text { presence of HIV } \\
\text { infection } \\
\text { - Establishing the } \\
\text { stage of the dis- } \\
\text { ease }\end{array}$ & & 2 \\
\hline 를 & $\begin{array}{l}\text { Accessing } \\
\text { patient care } \\
\text { components }\end{array}$ & $\begin{array}{l}\text { Ensuring that the } \\
\text { demand for } \\
\text { medicines will be } \\
\text { met }\end{array}$ & $\begin{array}{l}\text { Routing the } \\
\text { patients within the } \\
\text { regional health } \\
\text { system }\end{array}$ & & Obtaining medicine & 3 \\
\hline & $\begin{array}{l}\text { Patient's health } \\
\text { status improve- } \\
\text { ment }\end{array}$ & $\begin{array}{l}\text { Improving the } \\
\text { quality of drugs }\end{array}$ & & & $\begin{array}{l}\text { - Use of medicine } \\
\text { Obtaining psy- } \\
\text { chological assis- } \\
\text { tance }\end{array}$ & 4 \\
\hline & rimary activity & Inbound logistic & $\begin{array}{l}\text { Monitoring / } \\
\text { Preventing }\end{array}$ & Diagnosing & Intervening & \\
\hline & & $\begin{array}{l}\text { Forecasting the } \\
\text { need for consuma- } \\
\text { bles and medicines }\end{array}$ & $\begin{array}{l}\text { Mandatory medical } \\
\text { examination }\end{array}$ & $\begin{array}{l}\text { Identification of HIV } \\
\text { infection: ELISA/ } \\
\text { CLIA }\end{array}$ & $\begin{array}{l}\text { Infectious disease } \\
\text { doctors' and other } \\
\text { specialists' } \\
\text { appointments }\end{array}$ & 5 \\
\hline Perf & rming activities & $\begin{array}{l}\text { - Preparation of a } \\
\text { state assignment } \\
\text { - Drawing up an } \\
\text { annual procure- } \\
\text { ment schedule } \\
\text { - Preparation of } \\
\text { an application to } \\
\text { MHRF for provi- } \\
\text { sion of }\end{array}$ & $\begin{array}{l}\text { Voluntary medical } \\
\text { examination }\end{array}$ & $\begin{array}{l}\text { Dispensary } \\
\text { registration }\end{array}$ & $\begin{array}{l}\text { Laboratory and } \\
\text { instrumental } \\
\text { research methods }\end{array}$ & 6 \\
\hline & & $\begin{array}{l}\text { Purchases of } \\
\text { consumables (by the } \\
\text { Center and Perm's } \\
\text { authorized } \\
\text { organization) }\end{array}$ & $\begin{array}{l}\text { Organization and } \\
\text { implementation of } \\
\text { preventive meas- } \\
\text { ures }\end{array}$ & $\begin{array}{l}\text { Detection of the } \\
\text { stage of the disease } \\
\text { (see: [MHRF, } \\
\text { 2018a]): appoint- } \\
\text { ments of medical } \\
\text { specialists, usage of } \\
\text { instrumental } \\
\text { research methods }\end{array}$ & $\begin{array}{l}\text { Organization of } \\
\text { education for } \\
\text { patients }\end{array}$ & 7 \\
\hline & & $\begin{array}{l}\text { Purchases of } \\
\text { medicines (MHRF, } \\
\text { regional) }\end{array}$ & & & $\begin{array}{l}\text { Distribution of } \\
\text { medicines }\end{array}$ & 8 \\
\hline
\end{tabular}

B a sed on: [Porter, 1985; Porter, Teisberg, 2006]. 
Russian regions most prone to HIV infection, 2018 and 2019, cases per 100000 people

\begin{tabular}{l|l|c|c|c|c}
\hline \multirow{2}{*}{ Region } & \multirow{2}{*}{ Federal district } & \multicolumn{2}{c|}{ Morbidity } & \multicolumn{2}{c}{ Prevalence } \\
\cline { 2 - 6 } & & 2018 & 2019 & 2018 & 2019 \\
\hline Kemerovo region & Sibirskiy & 203.0 & 179.5 & 1700.5 & 1934.9 \\
\hline Irkutsk region & Sibirskiy & 160.7 & 130.1 & 1729.6 & 1906.2 \\
\hline $\begin{array}{l}\text { Sverdlovsk } \\
\text { region }\end{array}$ & Uralskiy & 157.2 & 125.6 & 1741.4 & 1828.1 \\
\hline $\begin{array}{l}\text { Chelyabinsk } \\
\text { region }\end{array}$ & Uralskiy & 154.0 & 130.1 & 1174.4 & 1324.0 \\
\hline $\begin{array}{l}\text { Novosibirsk } \\
\text { region }\end{array}$ & Sibirskiy & 142.8 & 124.9 & 1118.8 & 1281 \\
\hline $\begin{array}{l}\text { Perm region } \\
\text { Krasnoyarsk } \\
\text { region }\end{array}$ & Privolzhskiy & 140.8 & 118.1 & 1043.3 & 1188.1 \\
\hline $\begin{array}{l}\text { Tomsk region } \\
\text { Orenburg region }\end{array}$ & Sibirskiy & 114.1 & 116.6 & 914.8 & 1088.5 \\
\hline Tumen region & Uralskiy & 128.2 & 112.1 & 825.7 & 1010.6 \\
\hline
\end{tabular}

Note: the positions of the regions in the table are sorted (in the descending order) by morbidity in 2019.

B a s e d o n: [FSMCAPC, 2019].

Table 8

The Ansoff model for the expansion strategy option of the Perm HIV/AIDS-center

\begin{tabular}{l|l|l}
\hline \multicolumn{1}{|c|}{ Existing markets } & \multicolumn{1}{c}{ New markets } \\
\hline \multirow{2}{*}{ Service } & $\begin{array}{l}\text { (1) Market penetration - a significant } \\
\text { increase in the volume of services provided } \\
\text { to current consumer groups }\end{array}$ & $\begin{array}{l}\text { (2) Market development - provision of } \\
\text { current services to new geographic markets } \\
\text { and / or new consumer groups }\end{array}$ \\
\cline { 2 - 3 } & $\begin{array}{l}\text { Cannot be adopted since HIV-morbidity in } \\
\text { the Perm region is going down* }\end{array}$ & $\begin{array}{l}\text { Cannot be adopted, since, on the one hand, } \\
\text { the Perm HIV/AIDS-center operates on the } \\
\text { regional level and, thus, cannot expand its } \\
\text { activities geographically; and, on the other } \\
\text { hand, the center, in its activities, must } \\
\text { cover all the HIV/AIDS risk groups }\end{array}$ \\
\hline \multirow{2}{*}{$\begin{array}{l}\text { (3) Product development - expansion of } \\
\text { the range of provided services }\end{array}$} & $\begin{array}{l}\text { (4) Diversification - provision of new } \\
\text { services to new geographic markets and / } \\
\text { or new consumer groups }\end{array}$ \\
\cline { 2 - 3 } & $\begin{array}{l}\text { Cannot be adopted due to the current strict } \\
\text { regulation of services provided to HIV- } \\
\text { positive people }\end{array}$ & $\begin{array}{l}\text { Cannot be adopted due to the current strict } \\
\text { regulation of services provided to HIV- } \\
\text { positive people }\end{array}$ \\
\hline
\end{tabular}

Note: $*$ see Table 7 .

Bas ed o n: [Ansoff, 1957, p. 114; MHRF, 2018b]. 
bility, and retrenchment [Jauch, Glueck, 1988, p. 203].

The retrenchment variant is not an option in this case because the Perm region has one of the highest HIV-prevalence rates, and this indicator continues to increase (Table 7). If chosen, the expansion variant is usually elaborated within the Ansoff model (Product/Market Expansion Grid; [Ansoff, 1957, p. 114]) that implies creation of a set of activities as reflected in the corresponding matrix (Table 8). Unfortunately, neither of them is applicable in our case (Table 8). So, as our analysis indicates, the expansion variant is also not an option for the Perm AIDS center development, thus, the only variant left is stability.

In the context of the Ansoff matrix, the stability variant means implementation of a market penetration strategy while preserving of the volume and assortment of the services provided. Of course, the original idea of I. Ansoff ([Ansoff, 1957, p. 114]): "The company seeks to improve business performance either by increasing the volume of sales to its present customers or by finding new customers for present products," - is not directly applicable in our case. So, in this study, we suggest that the Perm AIDS center seeks to improve its business performance by means of increasing the effectiveness and efficiency of its activities.

Along with the "90-90-90" principle, by measures aimed at increasing effectiveness, we mean measures aimed at increasing the number of HIV-positive people who are:

- informed about their health status;

- receiving ART;

- improving their health.

In turn, by measures aimed at increasing efficiency, we mean measures aimed at reducing the costs of the Perm AIDS center.

So, according to aim of this study, specified in the introduction, we do not develop a fullfledged growth strategy for the Perm AIDS center, since, in particular, in this research we do not identify the center's opportunities and threats, and, correspondingly, do not discuss the measures to use / neutralize them. Instead, the paper proposes improvements to a number of the center's individual activities (forecasting, procurement, marketing) to contribute into its better performance. These improvements are described in the next section.

\section{STRATEGIC PLANNING OF THE PERM AIDS CENTER ACTIVITIES}

In this section, we discuss the ways to improve performance and cost-effectiveness of the Perm AIDS center via increasing the contribution of its individual activities (see rows $5-7$ in Table 6 ) to creation of value for the center's patients (rows 1-4 in Table 6) or reduction of the center's costs.

In particular, we demonstrate how to (Table 6):

1. Increase the marketing effectiveness of the center as related to informing the Perm city population about the HIV/ AIDS disease (cell B7 - cell B1).

2. Develop more powerful models for prediction of new HIV/AIDS cases (cell A5 - cell A3).

3. Improve the regulation of public procurement, at large, and the procurement of medical drugs for patients and consumables for diagnostic activities of the center (A6-A7 - A3-A4).

Points 2 and 3 also contribute to decreasing of the center's costs.

\subsection{The use of marketing tools to improve interaction with actual and potential HIV-positive citizens}

As of now, the Perm AIDS center communicates with potential carriers of the HIV infection and those who have been tested positive, basically, in a one-way manner - only via the center's web-site. To inform everyone interested about HIV/AIDS, the web-site is useful to do the following:

- get acquainted with educational materials on HIV/AIDS; 
- organize a visit to the center;

- call the hotline or contact by e-mail;

- get access to the activity "Lend a helping hand" through its VKontakte social network group.

Since one of the main objectives of the national policy is to counteract spreading of the HIV infection in the Russian Federation via informing citizens about the ways of prevention of getting HIV/AIDS, an integral approach was adopted on the federal level for such primary prevention. Within this approach, federal and regional campaigns are carried out that include different types of events in which regional AIDS centers play a key role.

As Table 9 demonstrates, these events are mostly aimed at the population at large - at least, not at targeted groups of population vulnerable to HIV/AIDS. To provide recommendations for the Perm AIDS center on how to increase targeting and, correspondingly, effectiveness of such events, we conducted our own pilot survey in spring 2019 in the Perm city $^{6}$. The survey was aimed at segmenting the Perm citizens into several target groups and detecting the optimal channels for communication on the HIV/AIDS problems with these groups.

${ }^{6}$ Due to the COVID-19 situation in 2020, the survey was conducted online via popular social networks. The questionnaire of the survey is available upon request.
The questionnaire comprised the following groups of questions (36 in total) on:

- part 1: socio-demographic characteristics of the respondents (such as age, education, income level, employment, marital status, having children, and level of IT skills);

- part 2: communication channels that are most convenient for the respondents.

In order to obtain and characterize the principal groups in this sample, we ran a hierarchical cluster analysis (using the Ward method). The optimal number of clusters four - was identified using formal criteria and supported by the relevant statistical tests (see [Gareth et al., 2017]). Based on these results, we were able to construct the typical "portraits" of Perm citizens, which, in turn, allowed to develop relevant recommendations on the channels for communication with them. Some descriptive statistics of the whole sample and the corresponding clusters are given in Table 10.

Based on the obtained information from Part 2 of our questionnaire, we identified specific characteristics of the four groups of citizens with regard to their attitudes toward the channels of communication. These characteristics are given in Table 11 along with specific recommendations for the Perm AIDS center on how to develop and realize the communication strategy with these groups. We

Table 9

HIV/AIDS events organized in the Perm region, 2019

\begin{tabular}{l|l|l}
\hline \multicolumn{1}{c|}{ Event } & \multicolumn{1}{c|}{ Content / The role of the Perm AIDS center } & \multicolumn{1}{c}{ Target group } \\
\hline $\begin{array}{l}\text { "Stop HIV/AIDS" } \\
\text { (twice a year) }\end{array}$ & $\begin{array}{l}\text { Seminars, round tables, flash-mobs, and lectures aimed at inform- } \\
\text { ing the population on the ways of transmission, protection, and } \\
\text { curing of the HIV disease. The center's employees give lectures at } \\
\text { local events, speak on radio and television, and publish different } \\
\text { printed materials }\end{array}$ & $\begin{array}{l}\text { All population } \\
\text { groups }\end{array}$ \\
\hline $\begin{array}{l}\text { "HIV-test: } \\
\text { Expedition" }\end{array}$ & $\begin{array}{l}\text { Free anonymous express HIV-testing. Mobile testing units are } \\
\text { organized in crowded places, where citizens are tested and can ask } \\
\text { HIV/AIDS related questions }\end{array}$ & $\begin{array}{l}\text { All population } \\
\text { groups }\end{array}$ \\
\cline { 2 - 4 } & $\begin{array}{l}\text { Conducting parent meetings where parents are consulted on how to } \\
\text { communicate with children on the HIV topic }\end{array}$ & $\begin{array}{l}\text { Parents of } \\
\text { children }\end{array}$ \\
\hline
\end{tabular}

PЖM 19 (1): 35-66 (2021) 
Table 9 (end)

\begin{tabular}{l|l|l}
\hline \multicolumn{1}{c|}{ Event } & \multicolumn{1}{c}{ Content / The role of the Perm AIDS center } & \multicolumn{1}{c}{ Target group } \\
\hline $\begin{array}{l}\text { "Peer to Peer } \\
\text { program" } \\
\text { (ongoing in the }\end{array}$ & $\begin{array}{l}\text { The Perm AIDS center, the Department of Education of the Perm } \\
\text { region, and the Center for psychological, pedagogical, medical and } \\
\text { Pecial assistance to children and adolescents of the Perm Industrial } \\
\text { District organize volunteering activities to give the volunteers } \\
\text { (students) the necessary knowledge about HIV/AIDS to transfer this } \\
\text { knowledge to their peers }\end{array}$ & $\begin{array}{l}\text { Adudents } \\
\text { studs and }\end{array}$ \\
\hline
\end{tabular}

Table 10

Socio-demographic characteristics of the sample, 2020

\begin{tabular}{|c|c|c|c|c|c|c|c|}
\hline Variable & Description & Value & $\begin{array}{l}\text { Whole } \\
\text { sample }\end{array}$ & $\begin{array}{c}\text { Cluster } \\
1\end{array}$ & $\begin{array}{c}\text { Cluster } \\
2\end{array}$ & $\begin{array}{c}\text { Cluster } \\
3\end{array}$ & $\begin{array}{c}\text { Cluster } \\
4\end{array}$ \\
\hline$N$ & $\begin{array}{l}\text { Number of } \\
\text { respondents }\end{array}$ & 126 & $100 \%$ & $35 \%$ & $24 \%$ & $11 \%$ & $30 \%$ \\
\hline Age & $\begin{array}{l}\text { Age of } \\
\text { respondent }\end{array}$ & $17-65$ years & 32.2 & 20.3 & 30.3 & 40.6 & 44.3 \\
\hline Education & $\begin{array}{l}\text { Respondent's } \\
\text { level } \\
\text { of education }\end{array}$ & $\begin{array}{l}\text { Likert scale: } \\
1 \text { - basic education, } \\
5 \text { - scientific degree }\end{array}$ & 3.4 & 2.6 & 3.9 & 4.0 & 3.6 \\
\hline Income & $\begin{array}{l}\text { Respondent's } \\
\text { level of } \\
\text { income }\end{array}$ & $\begin{array}{l}\text { Likert scale: } \\
1 \text { - very low, } \\
5 \text { - can afford whatever wanted }\end{array}$ & 3.7 & 3.8 & 4.0 & 3.6 & 3.5 \\
\hline $\begin{array}{l}\text { Marital } \\
\text { status }\end{array}$ & $\begin{array}{l}\text { Respondent } \\
\text { is married }\end{array}$ & $\begin{array}{l}1-\text { yes } \\
0-\text { no }\end{array}$ & 0.60 & 0.27 & 0.80 & 0.79 & 0.74 \\
\hline Children & $\begin{array}{l}\text { Respondent } \\
\text { has children }\end{array}$ & $\begin{array}{l}1-\text { yes } \\
0-\text { no }\end{array}$ & 0.52 & 0.0 & 0.57 & 1.0 & 0.89 \\
\hline IT skills & $\begin{array}{l}\text { Respondent's } \\
\text { IT skills }\end{array}$ & $\begin{array}{l}\text { Likert scale: } \\
1 \text { - absent, } 5 \text { - professional }\end{array}$ & 2.3 & 2.6 & 2.2 & 2.3 & 1.9 \\
\hline
\end{tabular}

Notes: numbers that are not \% represent average values of the corresponding variables; average values for binary variables represent the fraction of "yes".

Table 11

\section{Attributes of identified groups and recommendations}

\begin{tabular}{c|l|l}
\hline Cluster & \multicolumn{1}{|c}{ Features of the cluster } & \multicolumn{1}{c}{ Recommendation } \\
\hline 1 & $\begin{array}{l}\text { Having the highest level of IT skills, this } \\
\text { group uses social networks and smartphone } \\
\text { apps on a daily basis, as well as generally uses } \\
\text { online communication channels more often } \\
\text { than the citizens from other clusters } \\
\text { Also, this group values authority of the } \\
\text { information source and information security } \\
\text { (reliability, correctness, and promptness of the } \\
\text { information received) as the most important } \\
\text { characteristics of communication channels }\end{array}$ & $\begin{array}{l}\text { Cooperate with authoritative sources of informa- } \\
\text { tion. Influencers and various opinion leaders such } \\
\text { as bloggers, politicians, or doctors, can be reputa- } \\
\text { ble information sources } \\
\text { Using an approach that allows selecting the } \\
\text { target audience that meets the specified criteria, the } \\
\text { center can motivate this group to participate in the } \\
\text { every year) and in the "Peer to Peer program" (to } \\
\text { transfer the knowledge in a way that is comfortable } \\
\text { for adolescents) }\end{array}$ \\
\hline
\end{tabular}


Table 11 (end)

\begin{tabular}{c|l|l}
\hline Cluster & \multicolumn{1}{|c}{ Features of the cluster } & \multicolumn{1}{c}{ Recommendation } \\
\hline 2 & $\begin{array}{l}\text { This group prefers to use communication } \\
\text { channels in which it is not necessary to } \\
\text { interact with other people directly. They do } \\
\text { not distinguish between online and offline } \\
\text { communication channels, so they do not use } \\
\text { email to get more specific information and } \\
\text { are not willing to communicate with } \\
\text { specialists if necessary }\end{array}$ & $\begin{array}{l}\text { Shift focus from interpersonal communication } \\
\text { to mediated mass communication. This type of } \\
\text { contact implies the maintenance of specialized } \\
\text { groups in social networks and a well-organized } \\
\text { website, the publication in the press both } \\
\text { online and offline formats as well as the } \\
\text { development of a mobile application. It implies } \\
\text { provision of more events within the "Stop HIV/ } \\
\text { AIDS" program in the online format, for } \\
\text { example, publishing video materials from local } \\
\text { events in popular social networks }\end{array}$ \\
\hline 3 & $\begin{array}{l}\text { This group uses only social networks in } \\
\text { their day-to-day life and puts low priority } \\
\text { to other communication channels }\end{array}$ & $\begin{array}{l}\text { Create and support specialized groups in } \\
\text { popular social networks (such as VKontakte, } \\
\text { Instagram, Odnoklassniki) to provide relevant } \\
\text { information on the HIV/AIDS disease. For } \\
\text { example, it would be fruitful to create and } \\
\text { share guidelines on how to talk with children } \\
\text { about HIV within "HIV-test: Expedition" event }\end{array}$ \\
\hline 4 & $\begin{array}{l}\text { Being the most aged group, these people use } \\
\text { not only modern channels of information, } \\
\text { but also the classic ones, such as television. } \\
\text { Like Group 1, the people of this group } \\
\text { think that authority of the information } \\
\text { source is the most important attribute of } \\
\text { the information channel }\end{array}$ & $\begin{array}{l}\text { Cooperate with reputable sources to provide } \\
\text { information on HIV/AIDS. Influencers and } \\
\text { various opinion leaders, such as bloggers, } \\
\text { politicians, or doctors, can act as such informa- } \\
\text { tion sources. Having established the communica- } \\
\text { tional channels with this group, the center can } \\
\text { encourage these people to participate in differ- } \\
\text { ent events such as "HIV-test: Expedition" (to } \\
\text { take express HIV tests each year) and "Stop } \\
\text { HIV/AIDS" (to attend seminars and conferences } \\
\text { to get informed on the HIV/AIDS disease) }\end{array}$ \\
\hline
\end{tabular}

also provide the following (general) recommendations.

Recommendation 2.1.1. Change the structure of the web-site to increase convenience of information search and its overall usability. Also, develop a mobile version of the web-site.

Recommendation 2.1.2. The survey on the optimal information channels should be conducted on a regular basis by publishing the corresponding questionnaire both on the center's web-site and its accounts on social networks.

The results of this survey should be regularly analyzed to correspondingly adjust the marketing strategy of the center. The questionnaire of the survey was given to the specialists of the Perm AIDS center.

\subsection{Prediction of new registered HIV/AIDS cases}

\subsubsection{Introduction to the problem}

The status of the Perm AIDS center as a state institution implies that the center is mainly financed based on the so-called "state assignment". As the conducted personal interviews with several specialists of the center indicate, although the center has very detailed (weekly) information on new registered HIV/AIDS cases, to prepare and justify the state assignment for the corresponding year, the specialists of the center use quite naïve methods of new HIV/AIDS cases prediction (as described below in subsection 2.2.2). 
This resulted in the fact that in the state assignment of the center for 2020 and for the planning period of 2021 and 2022 (as approved by the Order of the Ministry of Health of the Perm region of 26.12.2019), the number of services to be provided remained unchanged (as compared to 2019) for all profiles of the primary healthcare: registration, visits to the center, and laboratory tests for new HIV/AIDS cases.

In accordance with Federal Law of the Russian Federation No. 44-FZ of 05.04.2013 "On the contractual system in the field of procurement of goods, works, services to meet state and municipal needs" (44-FZ), the Perm AIDS center, as a state institution, is a public buyer and is obliged to annually prepare and publish in the Russian unified procurement information system (UPIS) a procurement schedule of its purchases for the current calendar year (with subsequent adjustments).

As in any medical institution, the main part of the center's purchases consists of medical equipment, drugs, and consumables, in particular, diagnostic reagents. Correspondingly, the rapidness of use of these consumables depends on the number of conducted diagnostic and treatment procedures. The procurement schedule of the center is based on the planned volume of services to be provided within the state assignment, but, unfortunately, as of now, this schedule does not rely on modern methods of forecasting of new HIV/AIDS cases.

As we mentioned above, the Russian government freely provides HIV-positive people with the necessary drugs. Purchases of these drugs are mainly conducted by the Ministry of Health of the Russian Federation (MHRF) for all AIDS centers of the country (more details on this are given in Section 2.3). The necessary auctions are organized based on the prepared and appropriately justified applications by the regional AIDS centers.

As we already mentioned, when preparing such applications the Perm AIDS center does not use modern forecasting approaches to adequately predict the number of new HIV/ AIDS cases in the region. Thus, in this section, we demonstrate how to use such modern approaches and provide relevant recommenda-

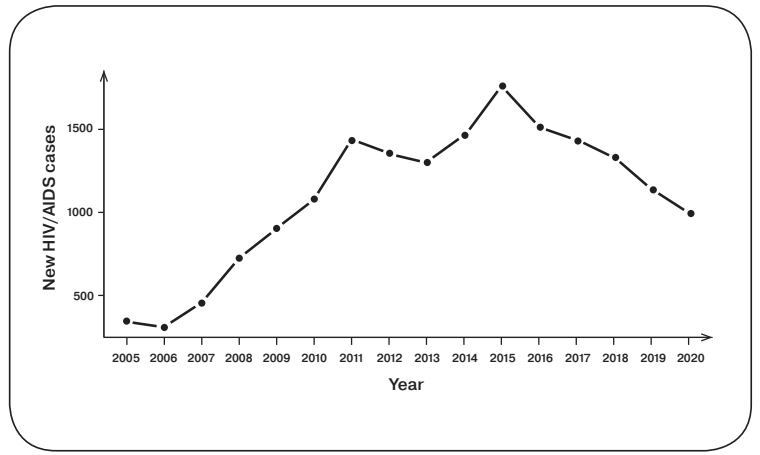

Fig. 6. Yearly dynamic of new HIV/AIDS cases in the Perm city, 2005-2020

B a s ed on: statistical data of the Perm AIDS center.

tions to better justify the state assignment and the procurement schedule of the center (Table 6, cells A6).

\subsubsection{Forecasting methods and results}

In this subsection we analyze the performance of the forecasting approach currently applied by the center and propose a modification to this approach. The calculations are made for yearly data - as required for the state assignment and the procurement schedule. The time series of the obtained data on new HIV/ AIDS cases for the Perm city over the period 2005-2020 is shown in Figure $6^{7}$.

The approach currently used by the Perm AIDS center specialists (as implemented in their MS Excel files) is basically described by the following econometric equation:

$$
\text { Cases }_{\mathrm{t}}=\alpha_{0}+\alpha_{1} \cdot t+u_{t} \text {, }
$$

where Cases is the number of registered $\mathrm{HIV} / \mathrm{AIDS}$ cases; $t$ is the time index; $u_{t}$ is the disturbance term. But, obviously, Eq. (1) is not the best choice for a time series like the one given in Figure 6.

${ }^{7}$ It is important to mention that in 2020 the number of new registered HIV/AIDS cases is lower than in 2019 due to both the general downward trend, and the COVID-19 situation which forced the Perm AIDS center to run less HIV tests. 
Accuracy of prediction of new HIV/AIDS cases by different models, 2016-2020

\begin{tabular}{l|c|c|c|c}
\hline \multicolumn{1}{|c|}{ Year } & $\begin{array}{c}\text { Actual number of } \\
\text { new registered } \\
\text { HIV/AIDS cases }\end{array}$ & $\begin{array}{c}\text { The center's } \\
\text { currently used } \\
\text { model* }\end{array}$ & AR(1)-model** & $\begin{array}{c}\text { Simplified } \\
\text { AR(1)-model } \\
\text { for MS Excel }\end{array}$ \\
\hline 2016 & 1512 & 1884 & 1722 & 1719 \\
\hline 2017 & 1433 & 1905 & 1471 & 1479 \\
\hline 2018 & 1329 & 1891 & 1397 & 1408 \\
\hline 2019 & 1136 & 1846 & 1115 & 1133 \\
\hline 2020 & 997 & 1756 & 9.0 & 9.6 \\
\hline $\begin{array}{l}\text { MAPE, \% } \\
\text { (over 2016-2019) }\end{array}$ & - & 40.6 & & 1399 \\
\hline
\end{tabular}

Note s: * - see Eq. (1); ** - see Eq. (2).

B a sed on: statistical data of the Perm AIDS center.

Using modern time-series econometric techniques, we analyzed the properties of the studied time series. A formal analysis of the time series of HIV/AIDS cases showed that this time series is stationary and has a highly statistically significant (partial) autocorrelation coefficient only of order 1 . So, we presumed that the time series may be quite adequately described by an autoregressive model of order 1, AR(1), of the following kind:

$$
\text { Cases }_{t}=\varphi_{0}+\varphi_{1} \cdot \text { Cases }_{t-1}+\varepsilon_{t} \text {. }
$$

In order to support this, we applied the following methodology. For several time periods that were taken cumulatively (2005$2016,2005-2017$, and so on up to 20052020), we used the following steps for each of the two models (Eq. (1) and (2)):

- test the corresponding time series for stationarity;

- estimate the models;

- construct a one-year-ahead prediction for each of the models.

Over all of the periods, the traditional tests of adequacy for the constructed autoregressive models demonstrated no specification problems. Moreover, we considered different number of lags in the autoregressive model, and the best specification was selected based on the Akaike information criterion (AIC).
Out of a wide range of specifications, AR(1) was always the best.

The results of one-year-ahead forecasting, as well as the mean absolute percentage errors (MAPE) of these forecasts are given in Table 12. As it can be seen from the table, the autoregressive approach (Eq. (2)) outperforms the naïve linear-trend approach (Eq. (1)), at least, four times, having MAPE of less than $10 \%$. The data for 2020 is given for information purposes only, since, as we mentioned above, in 2020, the number of new registered $\mathrm{HIV} /$ AIDS cases is lower than in 2019 due to both the general downward trend (Figure 6), and the COVID-19 situation which forced the Perm AIDS center to run less HIV tests.

The peculiarity of working with autoregressive models is that traditionally they are estimated using the maximum likelihood routine which is not implemented in MS Excel. But, since the specialists of the Perm AIDS center do their calculations in the MS Excel package, we developed and implemented a simplified version of the constructed AR(1)model to be used in this package.

To this end, we employed the basic facts about a stationary AR(1)-model to be able to calculate the estimates of its parameters (with use of the standard MS Excel functions CORREL and AVERAGE): 


$$
\begin{aligned}
& \varphi_{1}=\operatorname{corr}\left(\text { Cases }_{t} ; \text { Cases }_{t-1}\right) \varphi_{0}= \\
& \left(1-\varphi_{1}\right) \cdot \overline{\text { Cases }}_{t},
\end{aligned}
$$

where subscript $t$ represents years in the chosen time period.

So, the forecast for the next year can be obtained accordingly. As we can see in Table 12, the performance of the simplified AR(1)Excel model it is just slightly worse than the original AR(1) model (which is estimated by the maximum likelihood routine more precisely).

So, we come up with the following recommendation.

Recommendation 2.2.1. We recommend the Perm AIDS center to use the proposed (simplified) AR(1)-model to construct predictions of new HIV/AIDS cases for the forthcoming years (in the described manner).

More accurate prediction of the needs of the Perm AIDS center for medical drugs and consumables is expected to increase the overall quality of the center's annual state assignment, procurement schedule, and the corresponding application to MHRF for the drugs (Table 6, cell A5), as well as contribute to the patient value (cell A3) and help to cut the center's costs.

\subsection{Barriers to effective procurement of medical consumables and drugs: ways of identification and recommendations for removal}

\subsubsection{Public purchases of the Perm AIDS center in 2019: analysis and recommendations}

As noted above, due to its status of public body, the Perm AIDS center conducts its procurement activities in accordance with Federal Law of the Russian Federation No. 44 of 04.05.2013 on the Russian public procurement system (FZ-44). According to FZ-44 art. 26-1-3, public purchases for the center are conducted by the following institutions by:

- the Ministry of Health of the Russian Federation (MHRF) - to meet the cent- er's demand for drugs for the antiretroviral therapy $(\mathrm{ART})^{8}$;

- the Ministry for Regulation of the Contract System (MRCS) in the field of procurement of the Perm region (Russia) - in case of the initial contract price (ICP) of the auction is greater than $3 \mathrm{mln}$ rub.;

- the center itself in all other cases.

As we mentioned before, more accurate predictions of the needs of the Perm AIDS center for ART drugs is expected to increase the quality of the center's annual state assignment, procurement schedule, and the corresponding application to MHRF for the drugs (Table 6, cells A5-A6).

In this section, by analyzing the efficiency of the center's public procurement procedures in 2019 , we provide a set of recommendations to improve procurement of medical consumables and drugs (Table 6, cells A7-A8). These recommendations are aimed at: (1) improving the public procurement legislation (at large); (2) reducing the center's variable costs (which depend on the number of its new patients); and (3) increasing the value of medical care for the center's patients (Table 6, cells A3A4).

In 2019, the Perm AIDS center made 324 public purchases by itself, and 9 purchases were organized by MRCS for the center. The ICPs of all these purchases totaled more than $277 \mathrm{mln}$ rub. Out of the 333 procurement procedures, 332 were conducted via the electronic auction (e-auction) - with only 1 purchase made in the single-source procurement format.

In the literature, the following three conditions that are necessary for corruption to arise and persist are formulated (see [Aidt, 2003, p. F633]):

1) discretionary power: the relevant public official must possess the authority to

\footnotetext{
${ }^{8}$ Detailed examining of the MHRF procurements is out of the scope of this study. However, in $89 \%$ of its auctions (48 out of 54) over the studied period of time there was no competition [ITPC, 2019, p. 63].
} 
design or administer regulations and policies in a discretionary manner;

2) economic rents: the discretionary power must allow extraction of (existing) rents or creations of rents that can be extracted;

3) weak institutions: the incentives embodied in political, administrative, and legal institutions must be such that officials are left with an incentive to exploit their discretionary power to extract or create rents.

The current Russian public procurement policy is of explicit anti-corruption nature and is aimed at three principal things: (1) restricting discretionary power of contracting authorities; (2) preventing them from a rentseeking behavior; and (3) strengthening of institutions - or, in other words, the policy is aimed at not creating the three above-mentioned necessary conditions for corrupt behavior [Ivanov, 2016, p. 119].

The current public procurement policy considers the auction as a powerful anticorruption instrument as opposed to the single-source procurement. So, to restrict the discretionary power of a public buyer, the price auction is used as the main procurement method in the Russian Federation. Out of the four main types of auctions (the English auction, the Dutch auction, the Vickrey auction, and the request for quotations; see [McAfee, McMillan, 1987, p. 702]), FZ-44 allows to use only the English auction with the single (price) criterion and the request for quotations (when the ICP is not greater than 500000 rub.).

In the field of procurement, the English auction defines a procedure during which the price is successively reduced until there is only one supplier who is ready to provide the product or the service at the settled price. Since the English auction stops when the price drops below the reservation price (the lowest price until reaching which the supplier is ready to continue participating in the auction) of the last but one bidder (who quits the auction last), this auction allows identifying and fixing this price as the contract price and, accordingly, is called second-price auction (or the Vickrey auction).

Thus, the auction winner receives a "surplus" equal to the difference between the contract price and their reservation price. If only one bid is submitted or selected to participate in the auction, the bidding is not held, the contract price is set equal to the ICP, and the winner's "surplus" reaches its maximum.

The Russian procurement legislation permits the single-source procurement method for public purchases if the ICP does not exceed a certain threshold value. In 2019 , this threshold changed: before 30.07.2019 it was 100000 rub., and after this date it was changed to 300000 rub. Nevertheless, for a number of reasons - primarily, due to the above-mentioned anti-corruption nature of the Russian public procurement policy - the current practice is that even such "low-ICP" public purchases (purchases with ICPs below the threshold) are widely conducted via the e-auction [Ivanov, Ogorodova, 2017].

The current procurement practice of the Perm AIDS center is in line with the trend: in 2019, there were 167 e-auctions for "lowICP" public purchases. In our opinion, in these cases the single-source procurement method should have been used instead.

So, let us consider the financial (in)efficiency of using e-auctions instead of singlesource procurement procedures. In this analysis, we assume that expectation of a significant decrease of the ICP due to competition in the auction is the only reason to prefer the auction method over the single-source procurement method - neglecting the transaction costs that can arise due to the peculiarities of the current public procurement policy ${ }^{9}$.

A recent study conducted by experts of NRU HSE demonstrated that current average labor expenses of a public buyer to organize

\footnotetext{
${ }^{9}$ In the procurement practice, the enforcement authorities (Antitrust Service, Office of Prosecutor, Industry Public authorities, etc.) make much more efforts to control single-source procurement than e-auctions. Accordingly, contracting authorities need to waste resources and bear extra costs to neutralize this threat.
} 
Table 13

Financial efficiency of "low-ICP" e-auctions of the Perm AIDS center (as compared to single-source procurement), 2019

\begin{tabular}{l|c|c|c|c|c|c}
\hline \multirow{2}{*}{\multicolumn{1}{c|}{ Indicator }} & \multicolumn{6}{|c}{ ICP cumulative intervals (thousands of rub.) } \\
\cline { 2 - 7 } & {$[0 ; 10]$} & {$[0 ; 20]$} & {$[0 ; 30]$} & {$[0 ; 40]$} & {$[0 ; 50]$} & {$[0 ; 60]$} \\
\hline $\begin{array}{l}\text { Cumulative number of } \\
\text { auctions, units }\end{array}$ & 28 & 45 & 64 & 76 & 81 & 98 \\
\hline $\begin{array}{l}\text { Difference in labor } \\
\text { costs, hours }\end{array}$ & 448 & 720 & 1024 & 1216 & 1296 & 1568 \\
\hline $\begin{array}{l}\text { Difference in labor } \\
\text { costs, rub. }\end{array}$ & 127516.46 & 204937.17 & 291466.19 & 346116.10 & 368886.90 & 446307.61 \\
\hline $\begin{array}{l}\text { Aggregate ICP of the } \\
\text { e-auctions, rub. }\end{array}$ & 206247.78 & 349043.85 & 834445.79 & 1248884.17 & 1466186.07 & 2402265.42 \\
\hline $\begin{array}{l}\text { Maximum decrease of } \\
\text { the ICP in the e-auc- } \\
\text { tions, rub. }\end{array}$ & 51561.95 & 87260.96 & 208611.45 & 312221.04 & 366546.52 & 600566.36 \\
\hline $\begin{array}{l}\text { Financial result of } \\
\text { application of the } \\
\text { e-auctions (as compared } \\
\begin{array}{l}\text { to single-source } \\
\text { procurement), rub. }\end{array}\end{array}$ & -75954.51 & -117676.20 & -82854.75 & -33895.06 & -2340.38 & 154258.75 \\
\hline
\end{tabular}

B a s ed o n: [Balaeva et al., 2018].

an e-auction is 25.7 working hours while a single-source procurement requires only 9.7 working hours (for "low-ICP" contracts; see [Balaeva et al., 2018, p. 70]). Thus, organizing of an auction implies extra 16 working hours compared to single-source procurement.

In Table 13, for a number of "low-ICP" auctions, we calculated the difference between the maximum possible decrease of their ICPs (given the assumption of non-dumping behavior of the suppliers ${ }^{10}$ ) and the total extra labor costs of conducting these auctions. In our calculations, we used the following figures: (1) 38476 rub. - the average salary in the Perm region in 2019 [Rosstat, 2019]; (2) $30.2 \%$ - social security contributions rate; (3) 176 hours - working hours per month number.

\footnotetext{
10 The Russian public procurement legislation considers bids that decrease ICP by more than $25 \%$ as dumping ones.
}

In Table 13, we consider only the "low-ICP" auctions with the ICPs up to 60000 rub. This is just enough to illustrate the idea. As we can see from the table, in 81 out of 167 cases, application of the auction procedure was not economically reasonable. As to application of other "low-ICP" auctions (50 000 to 300000 rub.), we should keep in mind that this demonstration was made disregarding other important advantages of the single-source procurement procedure: the possibility to negotiate the quality of the supplied goods and delivering conditions, as well as avoiding such attributive auction risks as receiving no bids, a single bid, or a dumping bid, etc. ${ }^{11}$ [Ivanov, Ogorodova, 2017].

${ }^{11}$ For example, we should keep in mind the fact that an electronic trading platform typically takes $1 \%$ of the contract price as a fee from the auction winner, which imposes additional restrictions on the suppliers' reservation prices and, correspondingly, increases the public buyer's expenses [Avdasheva et al., 2020, p. 23]. 
Thus, we come up with the following recommendation.

Recommendation 2.3.1. We suggest that FAS annually checks validity of the procurement method choice by public buyers for "lowICP" contracts by applying an automated procedure in accordance with the methodology demonstrated in Table 13. When the procedure is used by FAS on the ex-post basis, public buyers will have an extra incentive for choosing the procurement method for "lowICP" purchases more responsibly.

Generally speaking, in this section we assess the efficiency of procurement of diagnostic reagents and treatment drugs for the patients undergoing dispensary observation at the center. The choice of this object for analysis here is justified by its dependence on the number of treated patients and by its contribution to the center's variable costs. Thus, increasing the quality of prediction of new HIV/AIDS cases (see Section 2.2) will allow to more precisely assess the volume of diagnostic reagents and treatment drugs to be procured, with the procurement procedures to be further analyzed and improved.

In accordance with the Order of the Government of the Russian Federation No. 471-r of 21.03.2016 "On the list of goods, works, services, whose procurement the buyer is obliged to conduct in the electronic form (e-auction)", certain medical products (including diagnostic reagents and drugs) - the list of them is called the Auction list - are procured exclusively by means of the e-auction ${ }^{12}$.

As the performance indicators for an eauction of the Perm AIDS center, we consider: (1) the number of participants in the auction (competitiveness); (2) the size of the ICP reduction (cost saving).

Let us analyze Table 14. In 2019, purchases of the diagnostic reagents were carried out both by the Perm AIDS center itself -22

\footnotetext{
${ }^{12}$ For procurement of goods from the Auction list (with the ICP of no more than 500000 rub.) request for quotations can be used. However, in the center's procurement in 2019 (as well as in the procurement of MHRF and MRCS), there were no cases of using it.
}

auctions (see cases 5-24 and 35-36), and by MRCS -4 auctions (see cases 1, 2, 28, 30), with the purchases of the latter accounting for more than $90 \%$ of the overall volume of the annual procurement. As for the treatment drugs, the center organized 6 e-auctions (cases 25-27 and 31-33), and MRCS - 4 ones (cases $3,4,29,34$ ), with the purchases of the latter also accounting for approximately $90 \%$ of the total procurement volume.

The analysis shows that out of 8 MRCS e-auctions, in 4 of them there was neither competition of the suppliers, nor ICP reduction; as for the center's purchases, the same was true in 25 out of the 28 auctions. Thus, in 29 out of 36 cases, single-source procurement would be a more adequate procurement method due to: (1) the chance for the buyer to directly choose consumables and drugs of the desired quality; (2) lower costs of the procedure itself for both the buyer and the supplier [Balaeva et al., 2018, p. 70]; (3) the possibility to negotiate the contract price and the delivery conditions.

Recommendation 2.3.2. Since procurement of medical drugs and consumables is usually repeated annually, it is not recommended to use the e-auction in the cases where competition cannot be anticipated based on the accumulated historical data on such procurements (if it is legally possible to use singlesource procurement or request for quotations).

Next, consider cases 28 and 29 in Table 14. Here we definitely identify a collusion of suppliers, because the second bidder did not submit any price offer after the competitor's initial price reduction of $0.5 \%$ of the $\mathrm{ICP}^{13}$. Under the conditions of a fair competition, this means that the second bidder's willingness to reduce the price is less than $1 \%$ of the ICP, so, this bidder will surely lose the auction when giving to the competitor a chance to bid first. Accordingly, the second bidder would act irrationally waiting for 2 minutes 26 sec-

13 The minimum auction step in Russian e-auctions is $0.5 \%$ of the ICP, the maximum is $5 \%$ (see 44-FZ, art. 68-6). 
onds (and even 1 minute 18 seconds), because in such situation the offer to reduce the price is made by the competitor who wins the auction. Therefore, it means that there was no fair competition in these two auctions.

Based on similar considerations, in case 30 we can also ascertain collusion with high probability, because it is very difficult to expect that a bona fide supplier who enters such an auction (with the ICP of more than 28 mln rub.) and wishes to reduce the price (by less than $2 \%$ ), would wait for 1 minute 44 seconds, thus giving the competitor a chance to place a bid - which may be up to $5 \%$ (!).

Thus, the only (out of 8 ) procurement procedure conducted by MRCS, where the form of e-auction is likely to be not less economically efficient than simpler procurement methods (single-source procurement, request for quotations), is case 34 . And it is only in this case (purchasing of Lopinavir and Ritonavir) that the auction can be chosen again as a procurement method for the next year. The same is true for cases $35-36$ - the purchases made by the Perm AIDS center - where there was a significant (close to dumping) price reduction.

Finally, several comments are to be made about purchases $31-33$ of the center. These three auctions were identical in the size and the object of procurement, and took place on the same day one after another.

In cases 31 and 32 , none of the three participants reduced the ICP during the auction - so, according to 44-FZ, art. 68-20, the contract was given to the supplier who first submitted the participation application to the e-auction (let us name this participant Supplier 1). But, in the absence of collusion, no one of the suppliers would know the time when the rival participants submitted their auction participation applications ${ }^{14}$, and, correspondingly, none of them would expect to win without lowering the ICP. Thus, in

14 The supplier admission protocol (publish before the auction starts) does not contain information on time when the auction participation applications were submitted.

Table 14

Procurement of reagents and medical drugs carried out for the Perm AIDS center, 2019

\begin{tabular}{|c|c|c|c|c|c|c|c|}
\hline $\begin{array}{l}\text { Purchase } \\
\text { No. }\end{array}$ & $\begin{array}{c}\text { Subject of } \\
\text { Procurement }\end{array}$ & $\begin{array}{c}\text { ICP } \\
\text { (mln rub.) }\end{array}$ & Buyer & $\begin{array}{l}\text { Number } \\
\text { of select- } \\
\text { ed } \\
\text { applica- } \\
\text { tions }\end{array}$ & $\begin{array}{l}\text { Number } \\
\text { of suppli- } \\
\text { ers that } \\
\text { decreased } \\
\text { price }\end{array}$ & $\begin{array}{c}\text { Decrease } \\
\text { in the ICP } \\
(\%)\end{array}$ & $\begin{array}{c}\text { Time of } \\
\text { first bid } \\
\text { after start } \\
\text { of the } \\
\text { auction } \\
\text { (min:sec) }\end{array}$ \\
\hline $1-2$ & $\begin{array}{l}\text { Reagent kits (test } \\
\text { systems) and reagents } \\
\text { for determining the } \\
\text { immune status }\end{array}$ & 49.04 & MRCS & 1 & 0 & 0 & - \\
\hline $3-4$ & $\begin{array}{l}\text { Etravirine and } \\
\text { Raltegravir }\end{array}$ & 26.40 & MRCS & 1 & 0 & 0 & - \\
\hline $5-24$ & $\begin{array}{l}\text { Reagents and consuma- } \\
\text { bles for biochemical } \\
\text { and bacteriological } \\
\text { research, supply of test } \\
\text { systems }\end{array}$ & 10.08 & Center & 1 & 0 & 0 & - \\
\hline $25-27$ & $\begin{array}{l}\text { Supply of Raltegravir } \\
\text { and Zidovudine }\end{array}$ & 2.33 & Center & 1 & 0 & 0 & - \\
\hline
\end{tabular}


Table 14 (end)

\begin{tabular}{|c|c|c|c|c|c|c|c|}
\hline $\begin{array}{l}\text { Purchase } \\
\text { No. }\end{array}$ & $\begin{array}{c}\text { Subject of } \\
\text { Procurement }\end{array}$ & $\begin{array}{c}\text { ICP } \\
\text { (mln rub.) }\end{array}$ & Buyer & $\begin{array}{l}\text { Number } \\
\text { of select- } \\
\text { ed } \\
\text { applica- } \\
\text { tions }\end{array}$ & $\begin{array}{c}\text { Number } \\
\text { of suppli- } \\
\text { ers that } \\
\text { decreased } \\
\text { price }\end{array}$ & $\begin{array}{c}\text { Decrease } \\
\text { in the ICP } \\
(\%)\end{array}$ & $\begin{array}{c}\text { Time of } \\
\text { first bid } \\
\text { after start } \\
\text { of the } \\
\text { auction } \\
\text { (min:sec) }\end{array}$ \\
\hline 28 & $\begin{array}{l}\text { Supply of reagent kits } \\
\text { (test systems) }\end{array}$ & 35.38 & MRCS & 2 & 1 & 0.5 & $2: 26$ \\
\hline 29 & Supply of Dolutegravir & 6.77 & MRCS & 2 & 1 & 0.5 & $1: 18$ \\
\hline 30 & $\begin{array}{l}\text { Supply of reagent kits } \\
\text { (test systems) }\end{array}$ & 28.60 & MRCS & 2 & 1 & 1.5 & $1: 44$ \\
\hline 31 & Supply of Dolutegravir & 0.69 & Center & 3 & 0 & 0 & - \\
\hline 32 & Supply of Dolutegravir & 0.69 & Center & 3 & 0 & 0 & - \\
\hline 33 & Supply of Dolutegravir & 0.69 & Center & 3 & 2 & 1.5 & $9: 45$ \\
\hline 34 & $\begin{array}{l}\text { Supply of Lopinavir } \\
\text { and Ritonavir }\end{array}$ & 11.93 & MRCS & 2 & 2 & 6.0 & $\begin{array}{l}\text { Not } \\
\text { relevant } \\
\text { for the } \\
\text { analysis }\end{array}$ \\
\hline 35 & $\begin{array}{l}\text { Supply of consumables } \\
\text { for bacteriological } \\
\text { research }\end{array}$ & 0.42 & Center & 4 & 4 & 23.5 & $\begin{array}{l}\text { Not } \\
\text { relevant } \\
\text { for the } \\
\text { analysis }\end{array}$ \\
\hline 36 & $\begin{array}{c}\text { Supply of consumables } \\
\text { for bacteriological } \\
\text { research }\end{array}$ & 0.06 & Center & 2 & 2 & 17.76 & $\begin{array}{l}\text { Not } \\
\text { relevant } \\
\text { for the } \\
\text { analysis }\end{array}$ \\
\hline
\end{tabular}

Notes: MRCS - the Ministry for Regulation of the Contract System in the field of procurement of the Perm region; Center - the Perm AIDS center.

these cases, collusion can be considered proved.

So, what should have happened in auction 33 ? If, in accordance with the agreement between the suppliers, Supplier 1 was to win all three auctions, they had no reason to change their behavior in the last auction. If the third auction was to be won by another supplier (let us name this participant Supplier 2 ), then this participant had to bid for a $0.5 \%$ price cut and win the contract.

But, opposite to this consideration, in auction 33 a "fierce" competition arose:
- Supplier 1 abruptly decreased by ICP by $1 \%$ (why not by $0.5 \%$ ?) 15 seconds before the end of the 10 minute period from the beginning of the auction ${ }^{15}$ (Why so late? In 15 seconds, the participant would be the winner);

- after that, in 1 minute - as the auction was prolonged for extra 10 minutes when

\footnotetext{
${ }^{15}$ According to Federal Law of the Russian Federation No. 44-FZ of 05.04.2013, art. 68-11, if there are no bids within 10 minutes, the auction ends automatically.
} 
Supplier 1 submitted the bid - Supplier 2 decreased the price by another $0.5 \%$ (down to the final $1.5 \%$ ) and became the winner.

Considering the procurement parameters of cases 31-33 (same drug, same ICP, same dates of solicitation to the auctions and conducting them) and such radical change of the suppliers' behavior in the last auction, it seems that the collusion was organized with participation of the public buyer, in the form of, so-called, bid orchestration [Lengwiler, Wolfstetter, 2006, p. 417].

\subsubsection{Recommendations on improvement of the Russian procurement regulation and practice}

In the previous subsection we studied 36 procurement procedures for medical drugs and consumables, which, according to the current Russian legislation, can be conducted only via the e auction. Of these procedures, only 3 auctions were actually competitive, including 2 "low-ICP" ones. Thus, it can be concluded that for the purchases under consideration, the e-auction was the least suitable procurement method among the available procurement options.

It seems that the situations of this kind stem from weakness of the Russian regulatory impact assessment system, which led to such changes in the public procurement regulation that allowed application of e-auctions disregarding the market conditions.

At the same time, the modern international practice of public procurement shows that a public buyer can use the auction procedure only if there is a competitive market of suppliers who are qualified to participate in the auction, so that an effective competition is ensured [UNCITRAL, 2011, art. 31-1]. A similar requirement was in the Russian legislation (see $94-\mathrm{FZ}^{16}$, art. 10-4) until the

\footnotetext{
${ }^{16}$ Federal Law of the Russian Federation No. 94FZ of 13.07.2005 "On State and Municipal Procurement of Goods, Works and Services”.
}

occurrence of 44-FZ: article 59-2 of 44-FZ excluded the presence of a competitive market from the conditions under which goods can be included in the Auction list.

Thus, the use of e-auction is currently possible within, basically, any market structure, including monopolistic. This, in combination with the Russian public policy aimed at restriction of discretionary power of public buyers, virtually destroys the Russian public procurement system, creating strong incentives for the auction to replace other procurement methods. As it was demonstrated above, this is already happening - $99.7 \%$ of the Perm AIDS center's purchases were conducted through e-auctions.

The evidence that reflects the low auction efficiency of purchasing of the studied medical products (drugs and consumables) on all levels (the center, MRCS, MHRF), indicates the inexpediency of their presence in the Auction list. Nevertheless, the rare cases of auction efficiency for purchasing of medical drugs and consumables (see cases 34-36 in Table 14) indicate that the e-auction can be used appropriately, but only when actual competition in the auction can be anticipated. Such justification is routine in the international practice [UNCITRAL, 2011, art. 28-3] and should be introduced to the Russian public procurement legislation and practice when waiver of the Auction List will politically become possible. Then, apparently, it will become impossible to improperly use the state budget funds (and other financial sources) when e-auctions are organized for "low-ICP" public purchases. So, our next recommendation is as follows.

Recommendation 2.3.3. following art. 31-1 of the UNCITRAL Model Law, amend article 59-2 of 44-FZ with a third condition for purchasing products from the Auction list of the following kind: "There is a competitive market of suppliers or contractors who are to be qualified to participate in the e-auction, so that effective competition is ensured".

In the analyzed 36 auctions conducted in 2019 to cover the needs of the Perm AIDS 
center (by MRCS and by the center itself), the suppliers' collusions were reliably identified in 5 cases - with yet another one case being very likely to have collusion. This is consistent with a well-known fact that the use of the English auction contributes to stability of collusion between the suppliers, since violation of the preliminary "agreement" between them by one of the participants can easily be ceased by the "appointed" winner directly during the bidding procedure [Kovacic et al., 2006, p. 388].

It should be noted that extremely favorable conditions for collusion of suppliers are created by articles $68-20$ and 71-3-4 of FZ-44. According to these articles, in the absence of a price reduction at the auction, the contract goes to the supplier who first submitted the application to the auction. But in the international practice, in such cases there is an option for the public buyer to cancel the procurement for the sake of public interest if there appears to have been a lack of competition or the presence of collusion [Guide, 2014, p. 81].

So, we recommend the following.

Recommendation 2.3.4. Amend article 71-3 of FZ-44 with the following condition: if in ten minutes after the start of the auction, none of its participants have submitted a bid, the auction is declared cancelled and the contract with none of the participants is not signed.

Recommendation 2.3.5. When purchasing those goods, works, and services that are not specified in the Order of the Government of the Russian Federation No. 471-r (the Auction list), use the auction format only if there is information about anticipated bona fide competition, and there was a decrease in price when purchasing such goods, works, and services previously.

It should be noted that if a public buyer procures some new products, such buyer can try to find information on similar procurements in the public procurement information system by other public organizations in the nearest location.

Generally speaking, Recommendations 2.3.1, 2.3.3, and 2.3.4 are aimed at improving the current Russian public procurement legislation. Recommendations 2.3.2 and 2.3.5 are formulated specifically for the Perm AIDS center and MRCS.

This recommendation is based on the abovementioned Model Law (art. 28-3), which requires, in particular, a mandatory justification for the use of any e-auction. Unfortunately, there may be certain administrative barriers to implementation of this recommendation. But the discussion of such situations is directly related to the regional governance of the public procurement system and is subject to further research. Nevertheless, implementation of this recommendation is still expected to increase the efficiency of the procurement process for the center.

\section{CONCLUSION}

As discussed in the paper, AIDS is the main cause of death for the Russian working-age population, which annually takes tens of thousands of lives and hinders the achievement of such goals of the Russian state policy as preserving the health and well-being of Russian people.

The main elements of the system of counteracting the spread of HIV/AIDS infection in the Russian Federation are regional AIDS centers, whose improvement of performance is required by the "State Strategy for Counteracting the Spread of the HIV Infection in the Russian Federation for the period up to 2020 and beyond".

The paper presents the activities of one of such centers - the Perm AIDS center - with help of a modified care delivery value chain (CDVC) model and gives methodological recommendations on its application for developing the center's growth strategy that has been identified as the classical strategy of market penetration.

A set of measures is proposed for increasing marketing effectiveness of the Perm AIDS center, improving the quality of new regis-

PЖM 19 (1): 35-66 (2021) 
tered HIV/AIDS cases prediction, and perfecting the procurement process of the center. These measures are expected to enhance the value of medical care for its patients and cut its costs, thus, improving the overall performance of the center.

\section{REFERENCES}

Aidt T. 2003. Economic analysis of corruption: A survey. The Economic Journal 113 (491): F632-F652. https://doi.org/10.1046/j.00130133.2003.00171.x

Ansoff I. 1957. Strategies of diversifications. Harvard Business Review September-October: 113-124.

Array Y., Verkhovskaya O., Klemina T. 2017. Strategy teaching at business schools: Contemporary challenges. Vestnik of Saint Petersburg University. Management 16 (2): 299-321. https://doi.org/10.21638/11701/ spbu08.2017.205 (In Russian)

Avdasheva S., Yakovlev A., Golovshchinsky K., Shamrin A., Podkolzina E., Orlova Yu., Korneeva D., Tkachenko A., Yusupova G., Balaeva O., Demidova O., Rodionova Yu., Kravtsova M., Chasovsky A., Yashchishens V., Dashkov S. 2020. Regulated Procurement in Russia: Yow to Increase the Stimulating Role of Budget Expenditures and Regulated Companies. Higher School of Economics. [Electronic resource]. https:// conf.hse.ru/mirror/pubs/share/359455190. pdf (accessed: 21.02.2021). (In Russian)

Balaeva O., Yakovlev A., Rodionova Yu., Esaulov D. 2018. Transaction costs in the sphere of public procurement of the Russian Federation: Assessment at the macro level based on microdata. Journal of Institutional Studies 10 (3): 58-84. https://doi. org/10.17835/2076-6297.2018.10.3.058-084 (In Russian)

FRIHOI. 2018. HIV Epidemic Situation in Russia in 2018. Federal Research Institute for Health Organization and Informatics of Ministry of Health of the Russian Federation. (In Russian)

FSMCAPC. 2019. Information about HIV infection in the Russian Federation. [Electronic resource]. Federal Scientific and
Methodological Center for AIDS Prevention and Control. http://www.hivrussia.info/ dannye-po-vich-infektsii-v-rossii/ (accessed: 21.02.2021). (In Russian)

Gareth J., Witten D., Hastie T., Tibshirani R. 2017. An Introduction to Statistical Learning with Applications in $R$ (7th ed.). Springer.

Golubeva A., Gilenko E., Dzhedzheya V. 2019. Enhancing public value of local public services through electronic interaction. Russian Management Journal 17 (2): 159-178. https://doi.org/10.21638/spbu18.2019.202

Guide to Enactment of the UNCITRAL. 2014. UNCITRAL Model Law on Public Procurement. United Nations Publications: N.Y. https://uncitral.un.org/sites/uncitral.un. org/files/media-documents/uncitral/en/ guide-enactment-model-law-public-procurement-e.pdf (accessed: 21.02.2021).

ITPC. 2019. The Analysis of Procurement of ARV Drugs in the Russian Federation in 2018. [Electronic resource]. International Treatment Preparedness Coalition. https:// itpcru.org/en/2019/06/18/the-analysis-ofprocurement-of-arv-drugs-in-the-russianfederation-in-2018/ (accessed: 21.02.2021).

Ivanov A. 2016. Quasi-corruption in Public Procurement: the case of Russian Federation. In: A. Teixeira, C. Pimenta, A. Maia, J. Moreira (eds). Corruption, Economic Growth and Globalization, 112-130. Routledge: London. https://www.econbiz.de/Record/quasi-corruption-in-public-procurement-the-case-of-the-russian-federationivanov-andrey/10011401117 https://doi. org $/ 10.4324 / 9781315776828$

Ivanov A., Ogorodova A. 2017. "Priceless" Procurement: Using Auction for Small Purchasing. Public Procurement: Management, Awarding, Provision 48: 46-55. (In Russian) 
Jauch L., Glueck W. 1988. Business Policy and Strategic Management (5th ed.). McGraw-Hill Book Company: N.Y.

Kaplan R., Porter M. 2011. The big idea: How to solve the cost crisis in health care. Harvard Business Review. [Electronic resource]. https://hbr.org/2011/09/how-tosolve-the-cost-crisis-in-health-care (accessed: 21.02.2021).

Kovacic W., Marshall R., Marx L., Raiff M. 2006. Bidding rings and the design of anti-collusive measures for auctions and procurements. In: N. Dimitri, G. Piga, G. Spagnolo (eds). Handbook of Procurement, 381-411. Cambridge University Press: Cambridge. https://doi.org/10.1017/ CBO9780511492556.016

Lengwiler Y., Wolfstetter E. 2006. Corruption in procurement auctions. In: N. Dimitri, G. Piga, G. Spagnolo (eds). Handbook of Procurement, 412-429. Cambridge University Press: Cambridge. https://doi. org/10.1017/CBO9780511492556.017

McAfee P., McMillan J. 1987. Auctions and bidding. Journal of Economic Literature 25: 699-738.

MHRF (Ministry of Health of the Russian Federation). 2018a. Order of the Ministry of Health of the Russian Federation of 20.11.2018 N 796n "On approval of the standard of primary health care for adults with a disease caused by the human immunodeficiency virus (HIV) (examination for diagnosis and preparation for treatment)". [Electronic resource]. http://docs. cntd.ru/document/551789902 (accessed: 21.02.2021). (In Russian)

MHRF (Ministry of Health of the Russian Federation). 2018b. Order of the Ministry of Health of the Russian Federation of 20.11.2018 N 797n "On approval of the standard of primary health care for adults with a disease caused by the human immunodeficiency virus (HIV) (preferred first-line antiretroviral therapy)". [Electronic resource]. http://base.garant.ru/72129270/ (accessed: 21.02.2021). (In Russian)

MHRF (Ministry of Health of the Russian Federation). 2019. National Projects
"Health Care" and "Demography". [Electronic resource]. https://minzdrav.gov.ru/ poleznye-resursy/natsproektzdravoohranenie (accessed: 21.02.2021). (In Russian)

Osunyomi B., Grobbelaar S. 2015. Integrating eHealth in HIV/AIDS intervention programmes in South Africa. South African Journal of Information Management 17 (1): 1-10. https://doi.org/10.4102/sajim.v17i1.623

Porter M. 1985. Competitive Advantage. The Free Press: N.Y.

Porter M. 2010. Value-based global health care delivery. Princeton Global Health Colloquium. [Electronic resource]. https://cutt. ly/GgkjrVc (accessed: 21.02.2021).

Porter M., Teisberg E. 2006. Redefining Health Care: Creating Value-Based Competition on Results (1st ed.). Harvard Business School Press: Boston.

Presidential Order. 2020. Executive Order of the President of the Russian Federation of July 21, 2020 N 474 "On the National Development Goals of the Russian Federation through 2030".

Rhatigan J., Sachin J., Mukherjee J., Porter M. 2009. Applying the Care Delivery Value Chain: HIV/AIDS Care in Resource Poor Settings. Working Paper 09-093, Harvard Business School.

Rosstat. 2019. Demographics. [Electronic resource]. https://rosstat.gov.ru/folder/12781 (accessed: 21.02.2021). (In Russian)

SanPin. 2011. Chief State Sanitary Physician of the Russian Federation. 2011. Resolution of the Chief State Sanitary Physician of the Russian Federation of 11.01.2011 N 1 (ed. from 21.07.2016) "On approval of sanitary and epidemiological rules 3.1.5.282610 "Prevention of HIV infection". [Electronic resource]. http://docs.cntd.ru/document/902256311 (accessed: 21.02.2021). (In Russian)

State HIV Strategy - Government of the Russian Federation. 2016. Russian Federation Government Decree of 20.10.2016 N 2203-r "State strategy for counteracting the spread of HIV infection in the Russian Federation for the period up to 2020 and further". [Electronic resource]. http://gov. 
garant.ru/SESSION/PILOT/main.htm (accessed: 21.02. 2021). (In Russian)

UNAIDS. 2014. 90-90-90: An Ambitious Treatment Target to Help End the AIDS Epidemic. [Electronic resource]. https:// www.unaids.org/sites/default/files/media asset/90-90-90_en.pdf (accessed: 21.02.2021).
UNAIDS. 2020. Global HIV \& AIDS Statistics - 2020 Fact Sheet. [Electronic resource]. https://www.unaids.org/en/resources/fact-sheet (accessed: 21.02.2021).

UNCITRAL. 2011. UNCITRAL Model Law on Procurement of Goods, Construction and Services with Guide to Enactment. United Nations Publications: N.Y.

Initial Submission:

February 25, 2021

Final Version Accepted:

June 20, 2021

\section{О некоторьх подходах к повышению эффективности деятельности региональных центров по профилактике и борьбе со СПИДол в России}

\section{А. Е. Иванов, Е. В. Гиленко, Е. М. Батуева}

Институт «Высшая школа менеджмента» Санкт-Петербургского государственного университета, Россия

В статье рассматривается проблема противодействия распространению ВИЧ/СПИД в России. СПИД является основной причиной смертности российского населения трудоспособного возраста, ежегодно уносящей десятки тысяч жизней и препятствующей достижению таких целей государственной политики, как сохранение населения, здоровья и благополучия людей. Основными элементами системы противодействия распространению ВИЧ-инфекции и СПИДа в РФ выступают региональные центры по профилактике и борьбе со СПИДом, совершенствования деятельности которых требует «Государственная стратегия противодействия распространению ВИЧ-инфекции в Российской Федерации на период до 2020 г. и дальнейшую перспективу». В статье на основе предлагаемой модификации модели цепочки создания ценности М. Портера при оказании медицинской помощи демонстрируется возможность увеличения эффективности деятельности регионального центра по борьбе со СПИДом путем повышения ценности оказываемых им услуг и сокращения издержек их предоставления за счет усиления каналов доведения информации о ВИЧ/СПИД до населения, повышения точности прогнозирования возникновения новых случаев инфицирования и совершения способов осуществления государственных закупок лекарственных препаратов и расходных материалов для его нужд. Расчеты в статье проводятся с применением современных количественных методов на реальных данных центра по профилактике и борьбе со СПИДом г. Перми. В результате формулируются релевантные рекомендации для руководства центра по осуществлению взаимодействия с населением, повышению качества прогнозирования новых случаев ВИЧ/СПИД и практики проведения государственных закупок лекарственных препаратов и расходных материалов для нужд центра.

Ключевые слова: региональные центры по профилактике и борьбе со СПИДом, модель цепочки добавленной стоимости в здравоохранении, государственные закупки, каналы коммуникации с населением, прогнозирование новых случаев заражения ВИЧ. 
JEL: C22; I18; H57

For citation: Ivanov A. E., Gilenko E. V., Batueva E. M. 2021. On some approaches to increasing performance and cost-efficiency of Russian regional AIDS centers. Russian Management Journal 19 (1): 35-66.

Статья поступила в редакиию 25 февраля 2021 г. Принята к публикации 20 июня 2021 г. 